\title{
Notas sobre la cultura alimentaria en la España del siglo XVIII
}

\author{
Juan Luis Suárez Granda
}

CES.XVIII, núm.19 (2009), págs. 257-297. 
Resumen: Los siglos XVIII y XIX asisten en Europa a una importante renovación de la cocina y al desarrollo de una autonomía del discurso sobre la comida con respecto a la medicina y a la religión. España no es ajena a esos cambios, en los que está presente la influencia francesa y, en menor medida, la italiana. No obstante, aun estando en la órbita de esos cambios, España está por debajo del nivel europeo, tanto en el número y entidad de los recetarios como en el confort y prestaciones de los establecimientos hoteleros, objeto estos últimos de frecuentes quejas de los escritores, tanto españoles como extranjeros. La cocina de la realeza española era refinada pero hipercalórica; la popular, tan simple y elemental como puede serlo ahora. Los recetarios españoles de la época obedecen a un patrón de cocina popular y modesta, y nacieron en su mayoría al calor de los conventos. Emplean ya algunos de los productos venidos de América, como chocolate, tomate y pimiento. No asi la patata ni el maíz, aunque tenemos constancia que ya se cultivaban y consumían en España.

Palabras clave: Gastronomía. Recetarios. Léxico. Viajes. 
Durante los siglos XVIII y XIX la alimentación y su ceremonial registran cambios muy importantes en varios países del occidente europeo, entre ellos España, cambios que conducen a la forma actual de entender la cocina y los rituales y normas de urbanidad en la mesa. Francia es en aquel momento el epicentro de las innovaciones culinarias y el gran modelo para toda Europa. La forma de cocinar se hace menos pesada y, de otra parte, cede la obsesión por la alimentación dietética e higiénica cuando el cocinero deja de ser un médico vergonzante: «La cocina, durante mucho tiempo sometida a la medicina, se liberó de ella, lentamente y sin alharacas, a lo largo de los siglos XVII y XVIII», dice Jean-Louis Flandrin ${ }^{1}$, y en otro momento matiza: «Todas estas precauciones higiénicas tienden a desaparecer en los siglos XVII y XVIII y todas las referencias de la antigua dietética se difuminan al amparo del nuevo gusto. Los cocineros y los gastrónomos sólo hablan de armonía de sabores y olvidan que los sabores hasta ese momento atañían tanto a los médicos como a ellos²». En suma, se abre paso una cocina presidida por la búsqueda abierta de sabores refinados, que no puede haber sido ajena a otros cambios sociales guiados por la afirmación de lo sensorial.

El propósito de este trabajo es mostrar datos acerca de la forma de alimentarse los españoles de aquella época, así como de lo que en una expresiva fórmula entonces se denominó civilidad de la mesa ${ }^{3}$, mediante un recorrido por los recetarios llegados hasta nosotros, muchos de los cuales, según los expertos, debieron de perderse, y otros circularían con toda probabilidad en copias manuscritas. Nos fijaremos también, aunque de pasada, en otros testimonios indirectos tales como tratados de agricultura, apicultura, viticultura, comercio,

1 Jean-Louis Flandrin, «De la dietética a la gastronomía, o la liberación de la gula», en Jean-Louis Flandrin y Massimo Montanari (dirs.), Historia de la alimentación, Gijón, Trea, 2004, pág. 865.

2 Jean-Louis Flandrin, «Los tiempos modernos», en Flandrin y Montanari, op. cit., pág. 708.

3 Encontramos la expresión en varios títulos: Jacques Delafosse, Civilidad de la mesa: rasgo de educación indispensable en todo sugeto de distinguido nacimiento. Contiene una definición de la verdadera civilidad, con el arte de trinchar todo género de viandas, el modo de servirlas con toda propiedad, y los documentos particulares de lo que se debe observar en la mesa, Imprenta Real de Madrid, 1790; y Ángel María DE LA TORRE y LEYva, Civilidad en la mesa, con el arte de trinchar todo género de viandas y de servirlas, 1795. Civilidad, sinónimo de urbanidad, se sustituyó por civilización. Un personaje de Ramón de la Cruz, harto quizá del encorsetamiento causado por las normas sociales dice: «La civilidad me trae / todas las tripas revueltas» («La civilización», 1763, en Ramón DE LA Cruz, Sainetes, Barcelona, Crítica, 1996, págs. 7-8). 
aguas medicinales, textos legales sobre comercio e higiene de alimentos, etcétera. Completamos la panorámica con un muestreo de textos de algunos escritores de aquel siglo.

\section{Un siglo de cambios}

En aquel periodo se consolida y configura, más o menos con la acepción actual, una buena parte de la terminología del ámbito de la restauración, comenzando por la propia voz restaurante (relacionado con el hecho de restaurar o reponer fuerzas), nombre que se da al establecimiento público que nace en Francia en el último tercio del siglo XVIII: «En los años anteriores a la Revolución, los restaurantes se multiplican. Sirven platos refinados por raciones, ya no en una improvisada mesa común, sino en pequeñas mesas cubiertas por manteles, mesas individuales o reservadas para un grupo de clientes. Los platos disponibles se escriben en una hoja enmarcada y, al final de la comida, se le presenta al cliente la "carta de pago", que no es otra cosa que la cuenta ${ }^{4}$ ». Perduran, no obstante, las antiguas ventas, fondas y posadas. En 1767, los hermanos italianos Gippini abren en Madrid la Fonda de San Sebastián, famosa por su tertulia, de la que eran asiduos, entre otros, Moratín padre, Iriarte y Cadalso. Según las leyes españolas de la época, en ellas estaba prohibido hablar de política, y sólo se permitía disertar sobre teatro, toros, amores y versos ${ }^{5}$.

En cuanto a los establecimientos de comidas y bebidas, España dejaba bastante que desear, según muchísimos testimonios, a algunos de los cuales acudiremos aquí. Para dar idea del atraso del país, basta considerar el contenido de una disposición de 26 de febrero de 1795, donde se establecen las condiciones por las que deben regirse las tabernas, y en las cuales puede leerse: «El vino ha de ser puro, legítimo y de buena calidad, sin mezcla alguna. / Las puertas deben estar siempre descubiertas. / Se prohíbe que a los días y horas de trabajo se detengan en dicha casa artesanos oficiales y aprendices de cualquier oficio; nunca hombres embriagados; y en ninguna ocasión se permitirá se detengan las mujeres en la citada taberna». En otro pasaje podía leerse: «Al tabernero no casado se le prohíbe tener por medidora y guisandera mujer que no llegue a la edad de cuarenta años poco más o menos ${ }^{6} »$.

\footnotetext{
4 Jean-Robert Pitte, «Nacimiento y expansión de los restaurantes», en Flandrin y Montanari, op. cit., pág. 944.

5 Fernando Díaz-Plaja, La vida española en el siglo XVIII, Barcelona, Alberto Martín, 1946, págs. 113-114.

6 Ibídem, pág. 114.
} 
La palabra gusto pasó, como metáfora estética, del paladar a las bellas $\operatorname{artes}^{7}$ durante los siglos XVI y XVII: «L'uso figurato del termine gusto introduce dunque un neologismo, di cui gli eruditi fanno risalire la diffusione, tra i modi di dire e di pensare, tra el XVI e il XVII secolo ${ }^{8}{ }$. Ambos usos ya aparecen claramente diferenciados en el XVIII. En su Dictionnaire philosofique (1764), Voltaire utiliza el termino en su doble acepción, en la cocina y en las artes plásticas:

El gusto, ese don de discernir nuestros alimentos, produjo en todas las lenguas conocidas la metáfora que expresa con la palabra gusto, el sentimiento de las bellezas y de los defectos en todas las artes: es un discernimiento inmediato, como el de la lengua y el del paladar, y que precede, como él, a la reflexión; es, como él, sensible y voluptuoso hacia lo bueno; rechaza, como él, lo malo con tesón [...]. Como el mal gusto en lo físico consiste en preferir siempre los condimentos demasiado picantes y demasiado rebuscados, así el mal gusto en las artes es apreciar únicamente los adornos complicados y no sentir la bella naturaleza 9 .

En 1739, los jesuitas Guillaume-Hyacinthe Bourgeant y Pierre Brumoy ya habían profundizado en la idea del buen gusto en la forma de alimentarse y consideraron la cocina como una de las bellas $\operatorname{artes}^{10}$. Paralelamente a ese reclamarse de la cocina como un arte — por ejemplo, Del arte de cocinar (1570), del italiano Bartolomeo Scappi-, se da su consideración como ciencia, y el francés Menon titula así dos de sus tratados de cocina, La Science du mâ̂tre d'hôtel cuisinier (1749) y La Science du maître d'hôtel confiseur (1750).

Los términos gourmet y gourmand, que aún hoy tienen en español la consideración de galicismos, pasaron del francés a otras muchas lenguas. Gourmet viene, en realidad, del inglés groomet, «criado». En Francia se llamó así al servidor responsable de catar los vinos en la bodega y llevarlos a la mesa. Gour-

$7 \quad$ Esa duplicidad no es, al parecer, exclusiva de la cultura occidental: «Vale la pena mencionar que el gusto sirve como metáfora estética no sólo en las teorías europeas sino también en la tradición mucho más antigua de la estética hindú», dice Carolyn Korsmeyer, El sentido del gusto. Comida, estética y filosofía, Barcelona, Paidós, 2002, pág. 19. Ya desde la antigüedad griega se desarrolló una jerarquización de la percepción sensorial, donde el sentido de la vista tuvo la mejor consideración por su contribución al desarrollo del conocimiento y al goce estético. Le seguían el oído y el olfato, el gusto y el tacto. Se estableció así una dicotomía entre sentidos «intelectuales» y sentidos «corporales» (Korsmeyer, op. cit., págs. 15-16).

8 Luca Vercelloni, Viaggio al gusto. L'odissea della sensibilità occidentale dalla societa di corte all'edonismo di massa, Milán, Mimesis, 2005, pág. 11. El mismo Vercelloni afirma en otro pasaje: «Nella storia del gusto, il xvIII funge da spartiacque tra l'apice ideológico della metáfora, che lo ha posto a fondamento della sensibilità spirituale, e la sua sucesiva dissoluzione. Ė infatti in questo scenario storico e culturale que, dopo un appaccionato dibattito, si consuma il divorzio tra il cerebrale e il viscerale [...], il senso del bello si allontana e si distingue dal piacere del palato» (op. cit., pág. 121).

9 Cit. por Flandrin, «De la dietética a la gastronomía», pág. 864.

10 Ibídem. 
mand es sinónimo unas veces de glotón y otras, de paladar fino ${ }^{11}$. Lógicamente, vale la pena detenerse en la voz gastronomía, que aparece en España en 1820. En Francia la encontramos impresa por primera vez en 1801. El ensayista francés Michel de Montaigne había acuñado en el siglo XVI una expresión mitad pedante, mitad castiza, «science du gueule» (ciencia del pico, o de la boca), que recubriría un campo léxico similar al de gastronomía. Pero sería, por tanto, un anacronismo emplear ese término para el siglo XVIII, toda vez que la primera ocasión en que se registra por escrito es en el libro del francés Joseph Berchoux, La Gastronomie (1801), cuya versión española en verso aparece en $1820^{12}$. La atención a la calidad antes que a la cantidad da idea del rumbo de la nueva cocina, a juzgar por estos ripios: «Como un artista comeréis realmente; / pero, ¡ay!, esto es comer muy parcamente». Y en otro pasaje se coloca también aquí la cocina entre las bellas artes: «Y en el lugar pondré que se merece / entre las bellas artes, aquél que trata / de la cocina y sus deleites ${ }^{13}{ }^{»}$.

En cuanto al régimen dietético, también hunde sus raíces en el mundo sajón de aquel entonces. «El concepto de régimen dietético — dice Deborath Lupton- no circuló a nivel popular hasta finales del siglo XVIII. Mientras en Francia se desarrollaban la gastronomía y la alta cocina, en Inglaterra y en los Estados Unidos del siglo XVIII nacían una ciencia nutricional y regímenes dietéticos que aspiraban a la contención del apetito en nombre de la buena salud y a la clasificación del valor alimenticio de los alimentos más que a la expresión de los nobles valores del refinamiento ${ }^{14}$.»

También del siglo XVIII es la aparición de café, primero para dar nombre a la infusión y después al establecimiento. Los cafés fueron desde el siglo XVIII lugares de encuentros y sociabilidad en las ciudades europeas. Para el español, Joan Corominas data la palabra hacia 1705, proveniente del turco kahvé, a través del italiano caffe. Russell P. Sebbold, por su parte, señala a Cadalso como primer autor que emplea la palabra café para referirse, no ya a la infusión, sino al establecimiento donde se toma esa bebida. En los Eruditos a la violeta (1772) leemos: «Las ciencias nos han de servir más que para lucir en los estrados, paseos, lunetas de las comedias, tertulias, antesalas de poderosos y cafés, y para ensoberbecernos ${ }^{15}$ ». El mismo Sebbold registra también el plural cafees en una comedia de Tomás de Iriarte, El señorito mimado (1772): «Como empezó /

11 Juan Cruz Cruz, Teoría elemental de la gastronomía, Pamplona, Eunsa, 2002, págs. 1-3.

12 La gastronomía o los placeres de la mesa. Poema por J. Berchoux. Traducido libremente del francés al verso español por don José de Urcullu, Valencia, 1820.

13 La gastronomía o los placeres..., ed. facs., Valencia, Librerías París-Valencia, 1993, págs. x y 3.

14 Deborah Lupton, Food, the Body and the Self, Londres, Sage Publicaciones, 1996. Citamos —y traducimos— de la edición italiana: L'anima nel piatto, Bolonia, Il Mulino, 1999, pág. 115.

15 José CADalso, Eruditos a la violeta, 1772, día I, sección primera. 
mi amo desde muy temprano [...] a frecuentar las insignes / aulas de Cupido y Baco, / cafees, mesas de truco, / nobles garitos, fandangos / de candil, y otras tertulias / perfumadas de cigarro ${ }^{16} \gg$. En el Madrid de la época fueron famosos los cafés La Fontana de Oro, El Ángel y La Cruz de Malta.

Otra voz que fechamos entonces es refresco, que consistía en algo más que una bebida refrescante y comprende, además de bebidas enfriadas con nieve, dulces y chocolates, y parece pensado para reponer fuerzas y agasajar a las visitas. Un personaje de Ramón de la Cruz dice: «Prevén confites y vino, / para que tome un refresco / la orquesta ${ }^{17}$ ». En tiempos de Felipe V y Fernando VI el refresco que se da a los guardias y alabarderos de palacio consiste en una bebida refrescante acompañada de algo más, parecido a lo que ahora entendemos por tentempié. Se menciona, por ejemplo, un refresco preparado con limonada, agua enfriada con nieve y bizcochos, otro consistente en pan y vino, en ocasiones acompañado de aceitunas y anises ${ }^{18}$.

El cocinero comienza a ejercer de forma autónoma, no ya ligado a la realeza y a las clases pudientes, cuando, ligándose en parte el fenómeno a la defenestración que entre la nobleza provocó la Revolución francesa, los antiguos profesionales que trabajaban al amparo de la aristocracia se hicieron independientes y abrieron sus propios establecimientos públicos de comida, donde se ofrecía al cliente la lista de platos de la que escoger. Estaba inventado el menú. Producto del afrancesamiento en la forma de comer, contar con un cocinero francés fue con el tiempo una de las aspiraciones de las clases pudientes españolas, moda que ridiculiza Ramón de la Cruz, por boca de Monsieur Andoville, protagonista del sainete El cocinero (1769):

$$
\begin{aligned}
& \text { El amo tiene gran gusto } \\
& \text { que le robe cuanto quiero, } \\
& \text { en poniéndole a la mesa } \\
& \text { dos guisados extrangeros. }
\end{aligned}
$$

Se comienzan a popularizar las reglas de urbanidad. He aquí un ejemplo de un manual español (Reglas de buena usanza civil, y christiana, 1767), que detalla normas higiénicas de la mesa, atribuye a cada comensal el uso de su

\footnotetext{
16 Tomás De Iriarte, El señorito mimado y La señorita malcriada, ed., introd. y notas de Russell P. Sebold, Madrid, Castalia, 1986, pág. 156, vv. 313-328.

17 Ramón de la Cruz, La Petra y la Juana o La casa de Tócame-Roque, en Sainetes, Barcelona, Crítica, págs. 261-262.

18 María de los Ángeles Pérez SAmper, «La alimentación en la corte española del siglo XviII», en Cuadernos de Historia Moderna, Madrid, Universidad Complutense, 2003, anejo II, págs. 175-176. Véase, más adelante, el «refresco general» que describe Juan de la Mata en su Arte de repostería.
} 
propio plato, cuchillo, cuchara, tenedor y servilleta, además de establecer las pautas jerárquicas de la mesa y a la conveniencia de no hacer ruido al comer o hacerlo con la boca llena:

Quando estás sentado en la mesa es muy indecente tener las manos o los brazos recostados sobre ella. También es gran grossería dar con el codo a los que tengas a los lados. / Es rusticidad ofensiva el tosser, escupir, y mocarse en la mesa; si no pudieres escusarlo, has de cubrirte la cara con la servilleta. / En los lugares que fuere costumbre conversar durante la comida, ten cuydado a no hablar jamás con la boca llena. / No llenes con demasía la cuchara cada vez que la encaminas a la boca, ni rasques con ruido el fondo del plato, ni tampoco el tuyo, porque estos golpes descubren, como señal seguro, tu golosina. / No has de llevar a la boca los huesos para sorber el tuétano, ni roerlos para limpiarlos en la carne, sino que con el cuchillo la cortarás en el plato y comerás después con el tenedor. / Es cosa indecente tocar la carne con las manos quando tengas tenedor, y mucho más aún manejar el pan con los dedos sucios, y lamerlos particularmente con ruido; enjúgalos con la servilleta. / No pidas de beber antes que el más calificado de la mesa haya bebido. Nunca bebas, que no hayas acabado de tragar el bocado; en bebiendo no levantes los ojos, y no te olvides de enjugar los labios. / No enjugues con la servilleta ni la cara, ni la nariz, ni el plato; es cosa incivil limpiar los dientes, y enjugar la boca en la mesa, y aún después de haver comido en presencia de los demás ${ }^{19}$.

Algunas otras palabras de este campo tienen su arraigo y su difusión en unos años en los que la sociedad gastronómica alcanza su protagonismo, entre ellas, nueva cocina (expresión utilizada a mitad del siglo por Matheo Hervé, cocinero de Carlos III), mancerina (plato para sujetar la jícara del chocolate), consomé (o caldo consumado, como también se llamó; los menús de la realeza española lo incluyen con mucha frecuencia ${ }^{20}$ ), sobremesa (ver más adelante, el padre Isla), sopa juliana (empleada durante el reinado de Fernando VI), sorbete, sumiller (responsable de la bodega), fiambrera (cestilla para las viandas de las comidas campestres), aparador, trinchero...

Por lógica, la popularización de todo ese vocabulario está ligada a la implantación de nuevos usos sociales y también a la aparición de unas obras, escri-

19 Reglas de la buena usanza civil, y cristiana. Utilissimas para todos, y singularmente para los que cuydan de la educación de los niños a quienes les deberán explicar, inspirándoles insensiblemente su práctica en todas las ocurrencias, Barcelona, 1767. Citado por Cruz CRUZ, op. cit., págs. 72-73.

20 Véanse los menús citados por María del Carmen Simón PALmer en La cocina de palacio, 1561-1931, Madrid, Castalia, 1977. En la página 139, por ejemplo, menciona un almuerzo de Felipe V en 1744, del que forma parte un «consumado o especie de caldo sin agua alguna, compuesto de la sustancia líquida de dos gallinas». 
tas no ya por cocineros o gente de la profesión, sino por ciudadanos que hablan de la comida, obviando las cuestiones de la salud y las creencias religiosas. En rigor, se trata de un cambio de trascendencia histórica porque la cocina es capaz de generar un discurso propio, inmanente, un discurso distanciado tanto de la religión como de la medicina. La gran biblia de este tipo de literatura llegará en el siglo XIX, Fisiología del gusto (1825), del francés A. Brillat Savarin, pero ya en el siglo XVIII hay aportaciones importantes. Nos referimos a un periodismo que con el tiempo ha conducido a lo que ahora llamamos crítica gastronómica. El creador de esa modalidad periodística es otro francés, Alexandre-BalthazarLaurent Grimod de la Reynière, autor entre otras obras de L'Almanach du comestible nécessaire aux personnes de bon goût et de bon appétit (París, 1781), que reseña y da cuenta de restaurantes y tiendas de comestibles, explicando a las nuevas clases poderosas lo que convenía comprar y comer en cada época del año ${ }^{21}$. En concordancia con la presencia de lo francés en el mundo de la cocina, es lógico que la terminología española esté salpicada de galicismos: aspic, ambigú, artalete, bechamel, blanqueta, borgoña, buffet, cava, consomé, corbella, chaudeau, champaña, champiñón, chef, crapaudine, foie-gras, fricandó, fricasé, furrier, gato (gateau), gofre, maître d'hôtel, menú, merengue, milhojas, mirabel, petisús, popieta, ragú, relevé, sopa juliana... Algunos de ellos se incorporaron al español en el siglo XVIII, otros en la centuria siguiente; algunos se han incorporado al patrimonio léxico español y otros han entrado en desuso.

A todas las novedades debe unirse otra muy determinante, producto de la expansión de rutas comerciales y de los descubrimientos geográficos. Nos referimos a la difusión del consumo de los alimentos provenientes de América (chocolate, patata, maíz, tomate, pimiento, haba, calabaza, cacahuete, girasol, piña, vainilla, pavo...) y de otros territorios (café, té, azúcar). Tanto el chocolate como el café y el té, según Alain Huetz de Lemps, eran consumidos sin edulcorar en sus países de origen ${ }^{22}$. La difusión de los nuevos productos fue desigual en tiempo y espacio, y en algún caso concreto, bastante lenta. Del mismo modo

${ }^{21}$ Publicó también otras obras, entre ellas Manual de anfitriones y guía de golosos (1808), breve compendio de cocina y etiqueta, con un pequeño anecdotario sobre algunos platos, como veremos más adelante. En una de sus ilustraciones, Grimod de la Reynière aparece tocado con gorro de cocinero, con el característico remate superior que recuerda a un bizcocho desbordando su molde. Su prosa da muestra de notable desenfado, vivacidad e incluso ingenio, como en aquella frase suya, que parece una greguería avant la lettre, donde dice que «el queso es el bizcocho de los borrachos» (B. A. Grimod dE LA Reynière, Manual de anfitriones y guía de golosos, Barcelona, Tusquets, 1998 [1. ${ }^{a}$ ed. 1980], pág. 99).

${ }_{22}$ Alain Hutz de Lemps, «Bebidas coloniales y auge del azúcar», en Flandrin y Montanari, op. cit., pág. 793. Para una visión de conjunto acerca de la integración en el entorno mediterráneo de los alimentos provenientes de América, véase el trabajo de María de los Ángeles Pérez SAmPER, «La integración de los productos americanos en los sistemas alimentarios mediterráneos», en La Mediterrània, àrea de convergencia de sistemes alimentaris (segles V-ХVIII), Palma de Mallorca, 1996. 
que el chocolate, el café, el té o el azúcar fueron acogidos con prontitud y llegaron a hacer furor, otros no comenzaron a consumirse hasta el siglo XIX. En cuanto al maíz, su cultivo en Europa fue verdaderamente precoz. Traído por Colón en 1493, aparece desde principios del siglo XVI en Castilla, Andalucía y Cataluña, para pasar casi al mismo tiempo a Portugal, Francia, norte de Italia y algunas regiones de Centroeuropa ${ }^{23}$. En torta y como gachas o polenta, el maíz llegó a ser alimento básico de las clases populares a las que pudo librar del hambre, con la contrapartida de que en una dieta descompensada y sin aportes vitamínicos trajo consigo la pelagra, una enfermedad diagnosticada por el doctor Casal, un médico catalán asentado en Asturias. Un hermoso bajorrelieve en madera de nogal de finales del siglo XVII o comienzos del XVIII, en una de las puertas de la catedral de Oviedo, representa a santa Eulalia regando campos sembrados de maíz en un idealizado campo asturiano. El tomate y el pimiento, que ya vemos empleados en varios recetarios españoles del siglo XVIII, están ausentes, sin embargo, de los de otros países de Europa. Por lo que se refiere a la patata, no aparece mencionada ni en los recetarios españoles ni en los europeos, lo cual hace suponer que se consideraba un alimento de baja condición, aunque fue componente básico en la dieta popular desde el siglo XVII, primero en Irlanda, Inglaterra y los Países Bajos, «y no antes del siglo XVIII en los demás países ${ }^{24}$ ».

Todo ese proceso de modernización conduce a lo que se ha dado en llamar nueva cocina y, como quedó dicho, tiene a Francia como centro de irradiación y, en menor medida, a los países de su entorno, particularmente Italia, aunque España, como estamos viendo, no es ajena a los nuevos aires. La llegada a España de Felipe $\mathrm{V}$ en 1700 trajo consigo la implantación de la cocina y los modos cortesanos franceses. Debemos pensar que en principio, más que el prestigio de la cocina del país vecino, lo que pudo ser determinante hubo de ser la procedencia francesa de la nueva dinastía. La influencia francesa en la corte española fue clara y duradera, por más que, como cabe imaginar, una cosa es la cocina de la corte y la nobleza y otra la de las mesas comunes. Por ejemplo, Juan Altamiras, un humilde monje franciscano, dice en el Prólogo a su Arte de cocina (1745): «No es mi intento escribir modos exquisitos de guisar, ya que para este fin ya hay muchos libros, que dieron a la luz cocineros de monarcas». Por lo demás, la cocina española ha arrastrado siempre bastante descrédito, a veces incluso en-

23 Los datos del cultivo del maíz los tomamos de Jean-Louis FLANDRin, «Los tiempos modernos», en FLandrin y Montanari, op. cit., pág. 697.

24 Hans Jurgen Teuteberg y Jean-Louis FLANDRIN, «Transformaciones del consumo alimentario», en Flandrin y Montanari, op. cit., pág. 895. Muy a finales de siglo (1785 y 1799) aparecen en Madrid dos manuales de Enrique Doyle — ¿traducidos del inglés? - sobre el cultivo y utilidad de las patatas (Simón PaLmer, Bibliografía de la gastronomía y la alimentación en España, Gijón, Trea, 2003, pág. 102). 
tre nosotros, y no es casualidad que haya hecho fortuna la frase de Julio Camba de que «la cocina española está llena de ajo y de preocupaciones religiosas ${ }^{25}$ ».

Aunque la verdadera modernización de la cocina europea tiene lugar en la Francia del siglo XIX, el XVIII, particularmente desde el último tercio, ya es el gran foco de irradiación de novedades culinarias. Por eso la llegada a España en 1700 de Felipe V, el primer Borbón español, determinó cambios importantes tanto en el ceremonial de la mesa como en la forma de comer de la corte. Ahora bien, como hemos dicho, una cosa eran los lujos palaciegos de monarquía y nobleza y otra la forma de comer del pueblo llano, de las clases medias, o la de los viajeros que recalaban en ventas y posadas levantadas al azar de los caminos.

El reemplazo de la comida española tradicional por la francesa no fue siempre un hecho fácil, y conoció situaciones de resistencia al cambio por parte española. Una anécdota sucedida en Figueras en 1701 con ocasión del banquete de bodas de Felipe V con su primera esposa, María Luisa Gabriela de Saboya, y recogida en sus Memorias por el duque de Saint-Simon, da muestra de ello:

Al llegar a Figueras el obispo diocesano los casó de nuevo con poca ceremonia y poco después se sentaron a la mesa para cenar, servidos por la princesa de los Ursinos y las damas de palacio, la mitad de los alimentos a la española, la mitad a la francesa. Esta mezcla disgustó a estas damas y a varios señores españoles con los que se han conjurado para señalarlo de manera llamativa. En efecto, fue escandaloso. Con un pretexto u otro, por el peso o el calor de los platos, o por la poca habilidad con que eran presentados a las damas, ningún plato francés pudo llegar a la mesa y todos fueron derramados, al contrario que los alimentos españoles, que fueron todos servidos sin percances. La afectación y el aire malhumorado, por no decir más, de las damas de palacio eran demasiado visibles para pasar desapercibidos. El rey y la reina tuvieron la sabiduría de no darse por enterados, y la señora de los Ursinos, muy asombrada, no dijo ni una palabra. Después de una larga y desagradable cena, el rey y la reina se retiraron ${ }^{26}$.

La controversia de gustos entre los paladares franceses y españoles era evidente, por más que el incidente anterior estaría reflejando una rivalidad de orden más complejo. La diferencia de gustos queda también reflejada en algún otro pasaje de las citadas memorias de Saint-Simon: «Fui recibido con mucha civilidad y buena comida, aunque a la española», dice en una ocasión. Y en otra: «En nuestro camino encontramos al marqués de Montealegre, y llegamos

25 Julio Camba, La casa de Lúculo, Madrid, Espasa Calpe, 1997, pág. 63 [1. a ed. 1937].

26 Duque de Saint-Simon, Mémoires, citado por Pérez Samper, art. cit., págs. 154-155. 
al mismo tiempo que él a la comida. Me envió a rogar que fuésemos a comer con él y también los señores que venían con nosotros. Iba muy acompañado, y rápidamente nos obsequió con una gran comida a la española, lo que nos hizo echar un poco en falta la comida que mis gentes habían preparado para nosotros ${ }^{27}$.

Al lado de las influencias francesas, deben mencionarse también las italianas. La segunda mujer de Felipe V, Isabel Farnesio, era de origen italiano y sabemos que el abate Albinoni, diplomático y gastrónomo, declara en una carta de 1715: «Soy admitido con la reyna, que no me regatea su confianza. Con insistencia me ha encargado que provea su mesa de los suculentos embutidos italianos y de buen vino de Parma. Ayer mismo me pidió que le enviase un plato de macarrones, a los que es aficionadísima». Y durante el embarazo de la reina se encarga de hacerle llegar de Italia trufas, salchichón, quesos, confituras y $\operatorname{vinos}^{28}$. A este respecto, otro dato que debe tenerse en cuenta es que Carlos III vivió largos años en Nápoles, de donde fue rey.

A lo largo de todo el siglo, la gran mayoría de los cocineros de la corte española eran de origen francés (incluso uno con nombre español, Antonio Catalán, había nacido en Francia), y aunque castellanizaron sus nombres, su apellido denota el origen ${ }^{29}$. En 1707 Francisco Desjardins sustituye a Juan Baptista Bernard, a quien acompaña en su cargo Jorje Chatelain. En 1709 llegan procedentes de Francia Pedro Benoist y Pedro Chatelain, que en 1710 aparecen como cocineros de la Servilleta de la Reina. Los apellidos de los cocineros reales que siguieron (Mercier, Concedieu, Blancar, Begue, Latour, Hervé, Levegué, Jacquemard, Guisciot, Canay) no dejan lugar a dudas. Hay que esperar a finales de siglo para encontrar dos nombre españoles, Manuel Rodríguez y Francisca Sánchez. Reinaba entonces Carlos IV: «Parece — dice Pérez Samper- como si el casticismo que impregnó la sociedad española a finales del siglo XVIII se hubiera contagiado también a los nombramientos de los cocineros. Ya no son franceses, sino apellidos de raigambre española los que ocupan los cargos de jefes de la cocina de boca ${ }^{30}$ ». Cocina de boca era el nombre que recibía el conjunto de tareas encargadas del suministro de alimentos del rey, de su familia y del personal del palacio, así como de la conservación de las vajillas, preparación de alimentos y servicio a la mesa. Había una complicada distribución de tareas, conocidas como oficios de boca, en muchas de cuyas denominaciones se delata el origen francés de la terminología: guardamangier (abastecimiento de carnes),

27 Ibídem, pág. 181.

28 Citado por Simón Palmer, La cocina de palacio, pág. 28.

29 Seguimos a Simón Palmer, La cocina de palacio, pág. 166 y sigs., y a Pérez SAmPer, art. cit., págs. 192-195.

30 Pérez SAmper, art. cit., pág. 195. 
panetería (pan, sal, palillos, leche y queso), cava (su jefe era el sumiller, responsable de bebidas y de la plata), sausería o salsería (vinagre y especias), frutería, potagería (verduras, cazuelas, escobas, cordel, papel), busería (del francés bous, «hervir», suministro de leña), furriería (colocación de sillas y limpieza de patios y escaleras), cerería y ramillete (ornamentación de mesas y mantelería) ${ }^{31}$.

Pérez Samper afirma que «la cocina cortesana de la monarquía española del siglo XVIII fue una cocina opulenta, refinada y cosmopolita, que respondía a los más elevados ideales gastronómicos y que se hallaba completamente diferenciada, por una parte, de la cocina cortesana de los Austrias, y por otra parte de la cocina popular, separada por una enorme distancia ${ }^{32}$ », afirmaciones con las que es fácil coincidir, aunque a un paladar de hoy le resultaría difícil armonizar opulencia y refinamiento; y como muestra copiamos dos menús cortesanos de la época para que juzgue cada cual:

Año 1723. Comida del infante don Felipe (tres años)

Sopa con sustancia de ave

Guisado con ave del tiempo

Asado con una pieza de ave de cebo

Huevos frescos a mediodía y noche

Un platillo de bollos y barquillos

$\mathrm{Y}$ ese otro:

Año 1726. Se sirve a la infanta María Ana Victoria (ocho años)

Almuerzo

Huevos frescos o sopa

Comida

Sopas: con una polla, con dos pichones

Platos: ternera asada, seis pichones rellenos, tres pollas

Asado: de siete piezas

Postre: torta de crema, pan relleno con pernil

Cena

Lo mismo

Además a mediodía trinchero con una polla y un perdigón

31 Simón Palmer, La cocina de palacio, págs. 81-94.

32 Pérez SAmper, art. cit., pág. 155. 
Los domingos: olla podrida

Los días de vigilia: cinco platos de pescado fresco y cuatro huevos ${ }^{33}$

No le va a la zaga este otro, servido en 1744 a Felipe V:

Un chaudeau o sopa ejecutada con dos yemas de huevo, azúcar, canela y vino de Borgoña; otra sopa con el nombre de consumado; trincheros con dos pichones de nido con sustancia; trincheros de mollejas de ternera emparrilladas con sustancia; trincheros de mollejas de ternera cocidas con sustancia; asado con dos pollas de cebo; cenaba el rey lo mismo excepto el caldo del almuerzo ${ }^{34}$.

Muy otro era el panorama que ofrecía la ancha geografía del país. Para dar idea del servicio que ofrecían las posadas, recogemos un testimonio entre los numerosos que podrían aducirse; se trata del interventor general de Hacienda francés Étienne de Silhouette, que recorrió España entre 1728 y 1730, y lo que dice contribuye al descrédito secular que, también entre los nativos, suscitaron por su precariedad las ventas y posadas españolas:

En casi todos los sitios se encuentran pollos; se los puede comprar y mandarlos matar al día. Se encuentra también mucha caza; el carnero es de suma delicadeza; se puede hacer provisión del mismo para dos días e incluso para tres, teniendo cuidado de mandarlo guisar. Se encuentran en todos los sitios huevos y son un gran recurso. Hay que llevar el cubierto, el vaso, las servilletas y un cepillito (porque hay posadas donde no lo hay), si no quiere pasarse sin almorzar ${ }^{35}$.

Las autoridades intentaban cambiarle la cara a los establecimientos públicos, y así una disposición de 1787 dispone:

1. ${ }^{\circ}$ Que en las fondas, cafés, hosterías y botillerías donde actualmente no se observa aquella decencia y curiosidad que corresponde, se pongan frisos de lienzo pintados, se blanqueen las paredes y se den [sic] de color a las puertas y mostradores.

2. ${ }^{\circ}$ Que a cada uno se sirva su plato limpio, aunque se junten tres o cuatro personas, pues, al sacar los vasos de la salvilla, se derrama la bebida sobre la mesa y a un leve descuido se mancha los vestidos y capas de los concurrentes.

33 Simón Palmer, La cocina de palacio, pág. 21.

34 Archivo del Palacio Real, Felipe V, legajo 261.

35 Citado por Alejandro Arribas Jimeno, El laberinto del comensal. Los oscuros símbolos de la comensalidad, Madrid, Alianza, 2003, pág. 205. 
3. ${ }^{\circ}$ Que los mozos sirvientes se presenten aseados, sin redecilla ni gorros y, si fuere posible, peinados.

$4 .^{\circ}$ Que no coman ni cenen a la vista del café o botillería y sólo puedan hacerlo en piezas interiores o sólo después de cerrar.

5. ${ }^{\circ}$ Que no se consienta el uso del tabaco de hoja y se ponga a la vista del público un letrero que diga: «Aquí no se permite fumar».

6. ${ }^{\circ}$ Que desde el primero de mayo hasta últimos de septiembre haya en las botillerías agua de nieve para servir (si alguno lo pide) a los que van a beber sorbetes y aguas heladas ${ }^{36}$.

Una comparación entre Francia, Inglaterra, Italia y España permite poner las cosas en su sitio en cuanto a la cantidad de recetarios de los cuatro países. Frente a los veintinueve libros de cocina publicados en el país vecino a lo largo de la centuria, a la decena larga dirigidos a cocineras, amas de casa y sirvientas editados en Inglaterra en los primeros cincuenta años del siglo y a los trece aparecidos en Italia durante el siglo ${ }^{37}$, el nuestro no alcanza la decena, como veremos a continuación.

Y si pasamos a lo cualitativo, los datos se nos muestran aún más significativos. Juzguemos la escueta receta de unas pobretonas «migas sin ajos» ofrecidas por Juan Altamiras en su Nuevo arte de cocina, por más que la receta comience con un candoroso preámbulo con ínfulas filosóficas:

Cualquier cosa se puede hacer sin ajo; pero muchas veces el ajo es el ser de cualquier cosa: para hacer migas sin ajo las cortarás menuditas, las mojarás con un poco de agua, y sal; pondrás cebolla a freír, y harás migas, picándolas bien, y las tostarás; y si quieres hacerlas sopas, les añadirás un poco más de agua, y las has de disponer a modo de una tortilla, volviéndolas de una à otra parte, déxalas tostar bien: son muy gustosas, y estomacales.

Y ahora, aunque por un momento desbordemos el ámbito del siglo XVIII, comparémoslas con la ampulosidad de la receta de Grimod de la Reynière en lo que él llama «De un asado sin igual ${ }^{38} »$. Se trata de una especie de receta matriocha, que tiene no poco de exhibicionismo, a la que el autor pomposamente atribuye el

36 Díaz-Plaja, op. cit., págs. 111-112.

37 Para Francia seguimos a Philip y Mary Hyman, «Imprimir la cocina: los libros de cocina en Francia entre los siglos XV y XIX», en FLANDRIN y MonTANARI, op. cit., págs. 811-812; para Inglaterra, a Christian Boudan, Geopolítica del gusto. La guerra culinaria, Gijón, Trea, 2008, pág. 347; y para Italia, a Alberto CAPATTI y Massimo Montanari, «Riferimenti bibliografici», en La cucina italiana. Storia di una cultura, Roma-Bari, Laterza, 2005.

38 Grimod de la Reynière, Manual de anfitriones, págs. 164-166. 
calificativo de «quintaesencia de las llanuras, de los bosques, de las marismas y lo mejor del corral». Ocupa dos páginas cumplidas, y en ellas se propone introducir sucesivamente una aceituna rellena de alcaparras y anchoas en un papahígo, que, a su vez, se introducirá en un hortolano, en una alondra, en un tordo, en una codorniz, que, «envuelta de una hoja de viña», irá dentro de un avefría, de un chorlito, de una perdiz, de una becada, que, envuelta en tocino, irá en el interior de un gallito de Guinea, de un pato, de una gallina, de un faisán, de una oca joven, de una pava, de una avutarda, que, rellena de «castañas, carne de cerdo picada, o cualquier otro sabio relleno», se colocará «en una cacerola de capacidad conveniente con cebollas picadas con clavo, zanahorias, tacos de jamón, apio, ramillete de aromas, trozos de tocino, pimienta, sal, especias finas, cilantro y uno o dos dientes de ajo». Tan recurrente preparado, ejemplo de inventiva ostentosa, debe cocinarse durante «veinticuatro horas en fuego lento y de manera que le penetre por igual y lentamente». Las instrucciones se rematan con la aclaración de que «se trata únicamente de seguir los principios enunciados en esta receta, es decir, de encerrar a todos los animales unos en otros, empezando por el más pequeño y aumentando así gradualmente del papahígo a la avutarda».

\section{Recetarios y otros textos sobre alimentación}

El amplísimo repertorio de María del Carmen Simón Palmer, Bibliografía de la gastronomía y la alimentación en España ${ }^{39}$, recoge más de cinco mil quinientas entradas desde el siglo XV a 1975, y en el capítulo correspondiente al XVIII encontramos 441. Aparte de los recetarios, aparece un amplio abanico de textos de diversa extensión sobre higiene alimentaria y normas de urbanidad, lactancia maternal, ordenanzas de oficios, abstinencia cuaresmal, propiedades medicinales de algunos alimentos, comercio, aguas medicinales, apicultura, cultivos, etcétera. Aquella cifra se duplica ampliamente en el XIX (1066 entradas), pero ese dato no debe hacernos minusvalorar la importancia de que se dotó en el XVIII todo lo referente a la alimentación, tanto en el orden culinario como en la medicina, el comercio y el ordenamiento jurídico.

La producción de recetarios de cocina en España, como acabamos de decir, no llega a la decena a lo largo de toda la centuria. Ahora bien, parece verosímil imaginar que, aparte de los conservados, debieron existir otros, normalmente manuscritos, que circularían en ámbitos reducidos —órdenes religiosas, por ejemplo— y que han debido de perderse.

39 Simón Palmer, Bibliografía de la gastronomía..., Gijón, Trea, 2003. 
El primer recetario europeo aparece en la España musulmana a principio del siglo XIII; se trata del conocido como Anónimo andaluz, un repertorio de más de quinientas recetas de cocina árabe-bereber ${ }^{40}$. Los repertorios de cocina constituyen un género del que estaba perdido el rastro desde el manual del mítico gastrónomo romano Apicio, De re coquinaria. El término receta estaba en su origen más relacionado con la herboristería y la farmacopea que con la cocina. Aún hoy, como sabemos, la palabra conserva su ligazón tanto con la medicina como con la cocina ${ }^{41}$. «En un sentido — dice Claude Fischler-, el cocinero y el médico proceden por prescripción: recepta es la "cosa recibida", la fórmula dada. En inglés, en alemán, en italiano, en castellano, en otras lenguas sin duda, el término derivado de recepta (recipe, Rezept, ricetta, receta) se aplica indiferentemente a la receta culinaria y a la prescripción facultativa ${ }^{42}{ }$.

El primero de los recetarios españoles de los que vamos a ocuparnos es un manuscrito en cuyo frontispicio leemos «en Pamplona», aunque sin datar, y parece haberse escrito, según Víctor Manuel Sarobe Pueyo, su editor, «a finales del XVII o comienzos del XVIII» o, más precisamente, se trataría de un original del XVII, copiado a finales de este siglo o comienzos del siguiente. Lo firma Antonio Salsete, ocurrente pseudónimo, y se titula El cocinero religioso ${ }^{43}$. Las muchas manchas de grasa que salpican el ejemplar tomado para la edición facsímil nos permiten deducir que estuvo más cerca de los fogones de una cocina monacal que del anaquel de su biblioteca. Contiene 318 recetas (50 de ellas de carnes), algunas de las cuales parecen tomadas del famoso libro de Francisco Martínez Montiño (Arte de cocina, pastelería, vizcochería y conservería, 1611), práctica bastante frecuente en este género de libros. Así, por ejemplo, otro clásico de la cocina española, Diego Francisco Granado (Libro del arte de cozina, 1599), copia muchas de las recetas del famoso libro del cocinero italiano Bartolomeo

40 Ha sido reeditado recientemente con el título de La cocina hispano-magrebí durante la época almohade, Gijón, Trea, 2005.

41 Algunos libros de los siglos XV a XVII son explícitos al respecto. Hay un Manual de mugeres en el qual se contienen muchas y diversas reçeutas muy buenas, recopilado entre 1475 y 1525, formado por 145 recetas reunidas por temas de forma desordenada, de las que 29 pertenecen al apartado de la alimentación. El Livro de receptas de pivetes, pastillas elvvas perfumadas y conservas, con 108 recetas de alimentación, cosmética, perfumería y medicina. Otro manuscrito del XVI, con adendas del XVII, consta de 207 recetas, de las que 105 son de cocina. Otro titulado Receptas experimentadas para diversas cosas, escrito entre los siglos XVI y XVII, que consta de 710 recetas de cocina, conservería, cosmética, perfumería, limpieza y medicina.

42 Claude Fischler, El (h)omnívoro. El gusto, la cocina y el cuerpo, Barcelona, Anagrama, 1995, pág. 227.

43 El título completo es El cocinero religioso. Instruido en aprestar las comidas de carne, pescado, yerbas, y potajes a su comunidad, introd., trasc. y notas de Víctor Manuel Sarobe Pueyo, Pamplona, 1995, ed. facs. [1. ${ }^{\text {a }}$ ed., 1990], págs. IX-XXII. El mismo autor ha estudiado otro recetario navarro del XVIII conocido como Recetario de Marcilla. 
Scappi, cuya obra Del arte de cocinar (1570) es un auténtico compendio enciclopédico de la cocina renacentista. El modesto recetario de Salsete contiene «recetas de guisos» muy simples y responde abiertamente a lo que era la cocina popular de la época. Emplea ya el pimiento y el tomate, dos de las verduras venidas de América, y además del empleo de este último para hacer salsa y una especie de pisto (cazuela de tomates), recomienda su uso en crudo para las ensaladas. Ello supone un adelanto de casi cincuenta años, por cuanto hasta ahora se venía considerado que era el manual de Altamiras (Nuevo arte de cocina, 1745) quien primero mencionaba el uso del tomate en un recetario ${ }^{44}$. No hace referencia, en cambio, a la patata, como tampoco lo hacen los demás recetarios del siglo. Los pimientos, cuyo uso se populariza verdaderamente en el XIX, aparecen, sin embargo, ya mencionados por Salsete («colorados, sin rabos ni pepitas») como conservantes — quizá molidos, en forma de pimentón- de morcillas, jamones y demás chacinería. Advierte en las recetas sobre la matanza ya «que [el pimiento] sirve para que se mantenga sin rancio». La importancia de la matanza del cerdo queda acreditada si consideramos que le dedica veinte recetas, mientras las salsas que recoge son dieciocho. El apartado de los postres es también escaso (bizcochos, torrijas bañadas en leche y enmeladas, natillas, arroz con leche), más otros cuatro añadidos tras el índice y con letra diferente (pestiños, buñuelos de viento, pudin y gañotes), incorporados, por tanto, más tarde. Algunos de esos postres están relacionados con la tradición árabe y judía, tan presente en la elaboración de las llamadas frutas de sartén (buñuelos, pestiños, churros, torrijas...).

Las recetas de Salsete son muy breves (alguna apenas rebasa las treinta palabras), como pone de manifiesto la de gazpacho, en la que, por cierto, no se emplea todavía ajo, tomate, ni pimiento:

Esta sopa se ha de hacer en barro, no en pieza de cobre por razón del vinagre. Se compone de pan migado, sal, agua, aceite, y vinagre y cebolla. En sabiendo templar el vinagre, se ha de hacer bien.

El estilo en que está redactado es siempre impersonal, excepto al final de la receta de «los pollos que se llaman carreteros», donde se permite un gracioso excurso: «Si el huésped es religioso suplirá y disimulará las faltas: si entendido, se hará cargo de que no hubo tiempo para más: si tonto pagará la pena de haber llegado tarde».

44 El agrónomo Gabriel Alonso de Herrera en su Obra de agricultura (1513) escribe: «Hay dos o tres especies de ellos. La planta lleva unas pomas aquarteronadas que se vuelven rojas y no tienen olor. Se dice que son buenas para salsas». 
El propósito de Salsete es modesto («el mismo uso te enseñará más que este cuadernillo, en el cual sólo se ha apuntado lo que basta para instruir a un principiante», dice en el prólogo) y, de hacer caso a sus palabras, hacía de cocinero por obligación: «No es asunto de este breve manual dar reglas al que por obediencia cuidare de la cocina para que haga religiosamente un oficio, del cual, si se practica como conviene, puede sacar un tesoro indecible de merecimientos, y virtudes». Como se ve está pensado para quien, cumpliendo el voto de obediencia, debe hacerse cargo de la cocina, si bien, delicadamente, parece sugerirse que no se excluyen algunos logros culinarios o, como el texto dice, el cocinero «puede sacar un tesoro indecible de merecimientos, y virtudes».

Ese breve prologuito contiene toda una declaración de principios -en parte, tal vez, vergonzante-, por cuanto, además del protocolario A. M. D. G. («todo ceda en mayor gloria de Dios», tópico de todas las acciones emprendidas por religiosos), excluye el placer de la mesa como fin de la cocina y dice que el cocinero «en todas sus acciones pondrá la mira únicamente en agradar a Dios». Si algo concede a la comida como fuente de placer («guisos delicados, y regalados»), no es pensando en la propia comunidad religiosa («nuestras pobres comidas») sino en «los enfermos inapetentes, y para los huéspedes extraños». El cocinero debe trabajar «como pide la caridad y la urbanidad», pero debe estar «atentísimo a que no se desperdicie, ni pierda cosa alguna del patrimonio de los pobres de Cristo», y por eso las instrucciones sobre «el modo de conservar las provisiones» están pensadas para «que se eviten gastos».

El Arte general de granjería (1711-1714) $)^{45}$, del dominico asturiano fray Toribio de Santo Tomás y Pumarada (1658-1714/1715), es un curiosísimo y extenso tratado (1300 páginas) que ha llegado hasta nosotros en una primorosa copia manuscrita, que su autor nunca pensó en publicar pues fue escrito para instruir a un sobrino, labrador de La Riera (Colunga). Si lo traemos aquí, aunque no sea un recetario, es por sus ricas y variadas referencias a la alimentación. Su contenido desborda ampliamente este campo concreto, pues en la parte de «Granjería espiritual» aborda tanto cuestiones teológicas como políticas o de comportamiento social, mientras en la de «Granjería material» se tocan temas de economía rural, agricultura, ganadería, arboricultura, arquitectura rural y fabricación de aperos de labranza. Es, por tanto, un compendio que suministra cuantiosos datos acerca de la vida rural, además de una guía espiritual cristiana en toda regla. Como fray Toribio está en todo, piensa incluso en cómo ha de

45 Fray Toribio de Santo Tomás y Pumarada, Arte general de granjerías (1711-1714), SalamancaGijón, San Esteban-Museo del Pueblo de Asturias, 2006, 2 vols., ed. y estudio preliminar de Juaco López Álvarez. 
ser la casa de su sobrino, con referencia precisa a sus plantas, su orientación y distribución. Por lo que toca a nuestro interés, vale la pena reproducir lo que dice de la despensa:

[...] en esta estancia se han de guardar las cossas que cada repiquete se necesitan, y que no es razón ocupar con ellas el horrio [sic], como son: grasa, aceite, miel, manteca, queso, saín [sebo], vinagre, cera y untos para medicinas, tocino, cecina y carnes de todos géneros, en particular las que de temporada en temporada es preciso irse gastando [...]. Y pónese a esta vanda la despensa, porque las cossas dichas consérvanse de prolijo con el ayre norte y cierzo ${ }^{46}$.

Son de interés también las consideraciones que se hacen sobre la conveniencia de que la casa disponga de su huerta, donde no debe faltar el perejil ( «Sin este cavallero ay mill guissos que no se pueden hacer $\left.{ }^{47} »\right)$, y apoya esa conveniencia en el saber del refranero («Cassa sin huerta siempre será tuerta»), para terminar afirmando: «Assí que la huerta para hortalizas, verduras, cebollas, ajos, berzas, repollos y otras cosas que diremos, no se puede negar que es un gran perteneciente para una cassa, por conducir a que aya en ella abundancia de vianda y llena ollazas para toda la familia ${ }^{48}$ ».

Al fraile dominico no le debían de ser ajenos algunos conocimientos de cocina, como pone de manifiesto la elaboración de una ensalada de lechuga, que denota un abierto ramalazo clasista: «Pero los amarillos cogollos apiñados, que quedan enteros, se comen assí crudos, quitándoles hoja por hoja hasta el tallo de adentro. Y para moje en el plato se desata miel, y algo de azúcar, en vinagre, la calidad de licor necesaria según las personas de messa. Si bien que para la gente ordinaria, vinagre basta por moje. Y éste es el uso entre comunidad de frailes ${ }^{49}$ ». Da instrucciones sobre los asuntos más variados de la agricultura: roturación de los campos, construcción de aperos de labranza, cultivo de colmenas y elaboración de la sidra. Confiesa sin empacho que con la peor fruta se hará la destinada a los criados: "Y con las [manzanas o peras] podres has de apartar las muy picapodres, y las ruinicas, y arrugadas, aunque sean bien sanas. La razón es porque destas segundas frutas debes hacer sidra aparte para criados, y obreros y otros lanzes, etc. Y de las frutas sanas has de sacar las sidras sanas, que te regalen y valgan sanos doblones ${ }^{50}$ ».

$46 \quad$ Ibídem, pág. 969.

7 Ibídem, pág. 994.

Ibídem, pág. 985.

Ibídem, pág. 994.

$50 \quad$ Ibídem, pág. 690. 
No se olvida nuestro fraile de las enseñanzas sobre la forma de comportarse a la mesa:

Ittem, ningún hijo, o hija (hasta estar cassados, o si el hijo es de orden sacro, sacerdote o religioso) se debe sentar a la messa a comer con sus padres; sino allí a un lado, en su mesa diputada para esso. [...] También para el modo de comer, que quiere ser con limpieza y aseo, se les ha poner para cada uno su cucharica tal qual. Porque es gran cochinada meter los cinco dedos por las sopas, y fabas, y otras viandas menudas, comiéndolas como a puñados. Assimismo es cochinada (y más en las hembras) limpiar al comer los dedos a su ropa, como dizen a la falda del sayu ${ }^{51}$.

Dejamos para el final los rotundos denuestos que hace fray Toribio del cultivo del maíz, que considera poco apropiado para Asturias y al que culpa de las hambrunas que padeció la región a finales del XVII y comienzos del XVIII («maíz famiento» y «negro y enemigo maíz», le llama). En su lugar propone otros cultivos:

Que ninguno siembre maíz en tierra o heredad alguna para negocio de cosecha, sino de otros granos según la calidad de la heredad, como escanda, trigo, centeno, cevada, yerbos, altramuzes, algarrobas y otras simientes que se estilan en las Castillas. [...] el maíz no es para fiar de él a la gente su común e ordinario sustento. Y está vista de experiencia, años ha, la razón. Porque tiene dos manifiestos peligros: o quemarle los calores y falta de agua, en julio y agosto; o quitarle de granar los fríos en septiembre y octubre ${ }^{52}$.

Las fuentes donde bebe fray Toribio en la parte dedicada a la cultura material están en una que él cita en la página 622, Libro de los secretos de agricultura, casa de campo y pastoril (1625, traducción del catalán), del que fue autor fray Miguel Agustín (1560-1630). De cualquier modo, muchos asuntos eran comunes en otros tratados agrícolas de la época, por ejemplo, el de José Antonio Valcárcel, Agricultura general, y gobierno de la casa de campo (Valencia, 1765-1795, 10 vols.).

Hay un recetario, del que hablamos sin conocimiento directo y al que ya se refiere Post Thebussem en su Guía del buen comer español (1929). Es el Libro de la cocinación, cuya copia manuscrita de 1740 fue encontrada en Cádiz por el archivero de su Facultad de Medicina por Rafael Picardo y era usado por los

$51 \quad$ Ibídem, pág. 204.

52 Ibídem, pág. 272. En otros dos pasajes de la obra (págs. 273 y 791-792) vuelve al mismo asunto y con parecidos argumentos. 
frailes capuchinos de la provincia de Andalucía. Incluye numerosas recetas en las que se emplea también el pimiento y el tomate.

Juan Altamiras, firmante del Nuevo arte de cocina $(1745)^{53}$, es el pseudónimo de fray Raimundo Gómez, monje franciscano nacido a finales del XVII en la Almunia de Doña Godina (Zaragoza), que ejerció en el Colegio Mayor de su orden en Zaragoza y en conventos de la provincia religiosa de Aragón. Su libro, que conoció ocho ediciones a lo largo del siglo, contiene unas doscientas recetas, casi la mitad de las cuales son de carnes y volatería. En cambio, de pescado sólo incluye treinta y siete y de huevos, diez. El resto son de «yerbas» (ensaladas), «escudillas» (potajes), algunos postres (buñuelos, arroz con leche), aguas con frutas o especias y algunos remedios para curar cortaduras y quemaduras. No menciona el pimiento, pero sí el tomate en dos recetas («Abadejo con tomate» y «Para conservar tomates»). El prólogo hace gala de la típica captatio benevolentiae oratoria, reforzada en este caso por la humildad del clérigo («Muchas cosas encontrarás, amigo lector, en esta cartilla, que por ventura te disonarán, por lo poco [sic] limitado del estilo»), e incide también en la modestia de su empeño pues «no es mi intento — dice- escribir modos exquisitos de guisar, ya que para este fin ya hay muchos libros, que dieron a la luz cocineros de monarcas» y «esta obrilla sirve sólo para aprendices». De igual modo, dice que su labor no es reflejo de una vocación, pues «forzado de la obediencia me hallé en el empleo de la cocina». En cuanto a las cualidades del cocinero, siguiendo la norma de otros libros anteriores del mismo porte, se menciona la virtud del ahorro y la economía («gaste con peso y medida», «lo calamitoso de los tiempos no permite desperdicios»), así como la limpieza (el cocinero debe ser «extremado en su limpieza», «en lo que viste [...] y en lo que guisa»), el orden («tenga todas las cosas en su sitio»), previsión («no se fíe en su habilidad para su desempeño», «se haga cargo de lo que ha de guisar y para cuántos») y la veracidad («la mentira no puede estar mucho tiempo oculta»).

Juan de la Mata, natural de Matalavilla (León), publica en 1747 su Arte de reposterí $a^{54}$, reeditándose otras cuatro veces a lo largo del siglo. Se trata del primer recetario español de este siglo escrito por un seglar, bien diferente de los que llevamos vistos pues, como su título indica, contiene recetas para

53 El título completo es Nuevo arte de cocina, sacado de la escuela de la experiencia económica, Madrid, 1745 [ed. facs. a partir de la ed. de 1767, Valencia, Librerías París-Valencia, 1999, pág. 120]. Se conserva otro recetario de repostería catalán de la segunda mitad del siglo: Joan BaPtista Panyó, Memorias del arte de cocina y pastelería y confituras y geleas.

54 El título completo es Arte de repostería, en que se contiene todo género de hacer dulces secos, y en líquido, vizcochos, turrones, natas: bebidas heladas de todos géneros, rosolís, mistelas, etc. Con una breve instrucción para conocer las frutas y servirlas crudas. Y diez mesas con su explicación. Su autor, repostero de esta corte, Madrid, Antonio Martín, 1747. 
preparados dulces; hay, no obstante, un capítulo dedicado a encurtidos (aceitunas, alcaparras, pepinos y pimientos) y dos recetas de salsa de tomate, pero están ausentes las carnes y los pescados; no así los huevos. En la mayor de las preparaciones interviene como ingrediente común el azúcar, pues el grueso del libro lo constituyen turrones, mazapanes, barquillos, bizcochos, compotas, mermeladas, jarabes, aguas heladas de frutas, pastillas acarameladas y licores de frutas. En otros casos, se emplean los lácteos como ingrediente básico. Un capítulo entero está dedicado al té, café y chocolate, y llaman la atención sendos capítulos dedicados al «modo de pegar cristales, vidrios y porcelanas» y a la preparación de una «pasta para lavar las manos». El último apartado es una explicación, a la que acompañan diez toscas ilustraciones que cierran el libro, con otros tantos modos de montar suntuosas mesas para diez, veinte..., y así hasta cien comensales. Dichas ilustraciones incluyen la ornamentación y los centros de mesa (ramilletes, se les llamaba entonces), formados por adornos de inspiración arquitectónica (pirámides, ciudadelas, arcos triunfales) que inducen a pensar que estemos en la antesala de la famosa frase del famoso cocinero francés del siglo XIX Carême («la arquitectura es una rama de la repostería»), la cual parece tener no poco de boutade, pero resulta indicativa del grado de barroquismo que adquirieron las presentaciones ornamentales de la cocina y la propia cocina. Y hay que tener presente que buena parte de esa «escenografía» ha llegado a la repostería y, curioso paralelismo, a la jardinería actuales. De la Mata rinde culto a aquella tendencia no sólo en la presentación de las mesas sino, por ejemplo, en las figuras de azúcar. Hay cierta vocación cosmopolita, podríamos decir, pues algunos preparados vienen apellidados como «a la portuguesa», «a la inglesa», «a la italiana» (el autor confiesa en el prólogo «haber sido discípulo de los mejores maestros que ha habido, así franceses como italianos, y de otras naciones»). Terminamos la reseña indicando que en el capítulo XXXI anuncia el modo de preparar el manjar blanco $0^{55}$, que, seguramente por olvido, no aparece después, y reproduciendo el «Modo que se debe observar para servir un refresco general». Es un pasaje muy ilustrativo de cuanto acabamos de decir respecto a la presentación ornamental de los manjares y de lo que entonces entendían por refresco:

55 El manjar blanco, plato del que quizá proceda el arroz con leche, se elaboraba con pechuga de paloma hilada, agua de rosas, azúcar, almendra, leche y harina de arroz. Aparece en el Livro de cocinha da infanta D. ${ }^{a}$ María de Portugal (manuscrito copiado en 1550) y después pasa a ser común en recetarios espanoles, franceses, italianos, ingleses y alemanes. Junto a la olla podrida y el miraus o mirraute (salsa catalana hecha con almendra, caldo, malvasía, agraz, zumo de naranja amarga y especias), el manjar blanco es una de las aportaciones españolas a la cocina europea. 
Un refresco general se previene con cuatro aparadores con la gente correspondiente, mas ó menos, según la función: uno, que es el principal para señoras, otro para señores, y otros dos para la demás familia y concurso. Estos estarán guarnecidos con manteles y bandejas, donde se colocarán los ramilletes, guarnecidos antes de todo género de dulces, estatuas y figuras de azúcar y caramelo, fuentes bastante capaces, con servilletas para poner todo género de dulces, huevos quemados, dobles, moles, \&c. Vizcochos largos para las bebidas. Tendrán también bastante género de bebidas, espumas de leche y chocolate, frutas heladas y pirámides, chocolate caliente, con sus vizcochos de Saboya, roscas ú otros generos que gustaren, salvillas y vasos, cucharitas para tomar las bebidas y frutas heladas, dulces en almivar, y azucar rosado. / Esto se podrá servir en la forma que sigue, según està puesto en práctica: Ya todo prevenido, se servirà primero las bebidas con vizcochos en cubiertos, armados, según se gustàre, y sus cucharitas en cubiertos: á esto siguen los ramilletes con pan en cubiertos, y todo gènero de dulces y huevos, y sus cucuruchos de papel: despues siguen las espumas heladas y frutas, tambien con sus cubiertos de cucharitas: luego el chocolate caliente; sus cubiertos de vizcochos de Saboya, tortas y vizcochos en rosca, bollos y pan tostado: luego se finaliza con el agua clara.

El siguiente es también un recetario de orden religiosa, los jesuitas. Su autor es Francisco Saravia, Común modo de guisar que observaban en las casas y colegios novicios de la Compañía de Jesús (1754) ${ }^{56}$. Recoge 127 preparaciones, la mitad de las cuales aproximadamente son de carne. El resto son guisos varios, potajes, huevos, algunas ensaladas, algunos postres (arroz con leche, torrijas, natillas, calabaza en arrope) y poco más. Menciona el pimiento (quizá se refiera al pimentón) en la preparación de las morcillas y, de los recetarios que estudiamos, es el único que ofrece la receta de olla podrida, precedente del actual cocido castellano, que reproducimos:

Después de partida la carne se echa en agua tres o cuatro horas para que desangre; se lava y se echa en la olla, echándole agua hasta que se cubra la carne, y se pone al fuego. En estando la espuma gruesa se saca con la espumadera, que tenga agujeros; échanse después los garbanzos, y se saca la espuma blanca que echan, y se echa la cebolla, y ajos, sal y el tocino, y se deja hervir hasta echarle las berzas, una, o dos horas después que se puso: en habiendo dado un hervor con las berzas se le echa la especia [fina: azafrán, clavo, nuez moscada y pimienta], y se sazona de

56 Título completo: Común modo de guisar que observaban en las casas y colegios novicios de la Compañía de Jesús de esta provincia que con cuidado deben aprender los hermanos coadjutores, Sevilla, 1754. 
sal, y se aparta hasta que haya de servir. Esta [la olla podrida] lleva de todas carnes, aves, conejos, carnero, jamón, vaca, etc. Hervirá a fuego manso, y en estando tierna se echa la especia fina, y si se quieren [sic] echarle vitualla que sea poca, y el caldo tasado, y con poca grasa: al principio se pone como la [olla] ordinaria.

El breve prólogo insiste, como ya hemos visto en otros casos, en las consabidas virtudes del cocinero (limpieza, orden, previsión) y algunos otros pasajes del mismo reproducen en los mismos términos las frases del Nuevo arte de cocina de Juan Altamiras. Estos plagios eran frecuentes y tomados muy probablemente con normalidad.

En 1784, Tomás de Aranguren, médico natural de Arganda, publica un libro sobre propiedades medicinales del vino, además de contener consejos para su cultivo ${ }^{57}$. Estudia el vino de la región toledana de Yepes y recomienda el llamado ojo de gallo para cortesanos, literatos y «todos aquellos que hacen poco ejercicio».

\section{El testimonio de los escritores}

En este apartado sólo aducimos textos de algunos autores del siglo, normalmente de una sola obra, dejando de lado, por supuesto, otras consideraciones que son las directamente relacionadas con el tema del artículo. No se nos oculta que la panorámica es incompleta, pero se entenderá que no pueda ser de otra manera.

Al principio decíamos que en el siglo XVIII la cocina desarrolla un discurso autónomo, independiente tanto de la medicina como de la religión. Sin embargo, la obra del monje benedictino fray Benito Jerónimo Feijoo (1676-1764) supone una regresión al respecto, por cuanto en su Teatro crítico universal (1726-1740) la alimentación está considerada justamente desde la perspectiva médico-religiosa. Cuando habla de la abstinencia cuaresmal, para él una y otra son, en rigor, la misma cosa, pues a cada paso menciona bien la autoridad de los médicos, bien la doctrina católica sobre la abstinencia cuaresmal, y el interés gustativo de los alimentos le es absolutamente ajeno:

57 El título completo es: Carta físico-médica en la que se explica qué es el vino, sus principios elementales, su variedad, los efectos que causa, así bebido con moderación como sin ella; las diferencias que hay de vinos, la distinción entre el blanco y el tinto, cuál de éstos es mejor para el uso común, y a quiénes conviene uno y otro; y qué deberá hacer el labrador para tener vinos saludables, para preservarlos de los vicios que suelen contraer, conservarlos y perfeccionarlos. 
Digo lo primero, que es incierto que los alimentos cuaresmales sean respectivamente a nuestra salud de peor condición que las carnes de los brutos. Véase, en prueba de esta conclusión, lo que dijimos en el I Tomo, Discurso VI, núm. 10 y 11, donde se hallarán varios autores médicos famosos, que no sólo conceden igualdad; más aun preferencia, en orden a prestarnos nutrimento saludable, a los peces, respecto de las carnes. Muchos más son los que Paulo Zaquías, en el lugar insinuado allí, alega al mismo intento. Las sentencias, que apunta de Hipócrates, y Galeno, no sólo prueban que los peces son buen alimento para los sanos, más aun saludables, por la mayor parte, a los enfermos; en tanto grado, que Hipócrates los prescribe por manjar conveniente en todo género de fiebres; y Cardano, siguiendo sus huellas, severamente reprehende a los médicos modernos, porque practican lo contrario $^{58}$.

Sigue además continuamente las teorías médicas de Hipócrates, las cuales establecían que la salud radicaba en un equilibrio entre cuatro diferentes sustancias básicas o humores (colérico, melancólico, sanguíneo y flemático), de modo que la enfermedad resultaba de un exceso o déficit de alguno de esos cuatro humores. Los alimentos eran clasificados de acuerdo con aquel criterio, pues tenían propiedades que los hacían saludables o desaconsejables, ya que enfermaban o ponían el cuerpo en su sitio:

Los peces, además de esto, entre todos los animales, son los más fecundos, ágiles, y sanos: ni hay historia de peste alguna, o contagio, que hayan padecido; de donde parece se infiere darán un alimento también más sano, y apto para conservar la salud y robustez. Las carnes son proporcionadas para llenar el cuerpo de crudezas, y pútridos humores, de donde se siguen diarreas, vértigos, gotas, calenturas, y apenas hay dolencia, que no pueda seguirse a esto; por lo cual es adagio, que carnivoram animam non amat bona valetudo. [...] Respecto de otros alimentos cuaresmales, como leche (a los que es permitida), frutas, yerbas, legumbres, subsisten las mismas razones que militan a favor de los peces: esto es, su mal fácil atenuación, y digestión, no abundar tanto de partículas sulfúreas, y salinas, \&c. Por lo cual los autores médicos muy frecuentemente recomiendan la leche bien condimentada como un excelente alimento; y de yerbas, frutas, y legumbres, dan muchas por sanísimas. Y aun cuando en unas, u otras se reconociese algún vicio, es manifiesto que con la cocción, y el condimento es fácil corregirse ${ }^{59}$.

58 Fray Benito Jerónimo Feijoo, Teatro crítico universal, tomo séptimo, discurso novo, II, núm. 3.

59 Ibídem, discurso novo, II, núms. 7 y 9. 
En otra parte de su obra («Razón del gusto»), Feijoo se ocupa también del tema del gusto tanto en sentido gustativo como estético, establece la diferencia entre gustos innatos y gustos adquiridos, y en lo que respecta al sentido gustativo dice:

El manjar que, usado por algunos días, es gratísimo, se hace ingrato continuándose mucho. La sensación del paladar es la misma, como cualquiera, que haga reflexión, experimentará en sí propio; pero la consideración de su repetido uso excita una reprehensión fastidiosa, que le vuelve aborrecible. De esto hay un ejemplo insigne, y concluyente en las Sagradas Letras. Llegaron los israelitas en el desierto a aborrecer el alimento del maná, que al principio comían con deleite. ¿Nació esta mudanza de que, por algún accidente, hiciese en la continuación alguna impresión ingrata en el órgano del gusto? Consta evidentemente, que no; porque era propiedad milagrosa de aquel manjar, que sabía a lo que quería cada uno: Deserviens uniuscujusque voluntati, ad quod quisque volebat convertebatur. ¿Pues de qué? El texto lo expresa: Nihil vident oculi nostri, nisi man. Nada ven nuestros ojos sino maná. El tener siempre, todos los días, y por tanto tiempo una misma especie de manjar delante de los ojos, sin variar, ni añadir otro alguno, excitó la aprehensión fastidiosa de que hablamos.

Muchos no gustan de un manjar al principio, y gustan después de él, porque oyen que es de la moda, o que se pone en las mesas de los grandes señores: otros, porque les dicen que viene de remotas tierras, y se vende a precio subido. Como también al contrario, aunque gusten de él al principio, si oyen después que es manjar de rústicos, o alimento ordinario de algunos pueblos incultos, y bárbaros, empiezan a sentir displicencia en su uso. Aquellas noticias excitaron una aprehensión, o apreciativa, o contemptiva, que mudó el gusto. En los demás sentidos, y respecto de todas las demás especies de objetos delectables, sucede lo mismo ${ }^{60}$.

Dando muestra de una enorme potencia verbal y un expresionismo descriptivo que recuerdan a su maestro Quevedo, Diego Torres de Villarroel (16931770) presenta en los Sueños morales (1727-1728) sendos alegatos moralizantes contra el alcoholismo y contra la gula. En la «Visión y visita tercera» de la obra, los excesos alcohólicos son el objeto de la diatriba. Un Quevedo redivivo acompaña al autor por las calles de Madrid:

Iba Quevedo, sin mover las pestañas, repasando tiendas, ojeando tablillas y construyendo la descuadernada greguería de oficios que hay en la Red de San

60 Ibídem, tomo sexto, discurso undécimo, III, núms. 16 y 17. 
Luis; y a veces miraba con un ceño tan desagradable, que más terrible se hacía con lo airado, que con lo difunto. Yo también marchaba a su izquierda, confuso y atolondrado el celebro de discurrir el motivo, la ocasión y el modo de venirse Quevedo a la corte.

Contemplan los «puestos de rosolíes, mistelas y aguardientes» y, testigos de la desmedida afición por los licores que reina a su alrededor, discurren a porfía, horrorizados de cómo «se ha hecho razón de estado la borrachera y pasa por cortesano montés y político zafio el que no hace provisión abundante de esas zupias». Y termina así la perorata:

Las mistelas — volvió a decir Quevedo- y toda esta casta de vinos espirituosos y volátiles los gastaban en mi siglo los desahuciados por la medicina y la naturaleza, aplicándolos a la nariz para que por sus conductos pasasen a alentar celebros descaídos y pulsos remolones. Y hoy se usa más que el agua. ¡Válgame Dios! Si volviera a ser viviente, por no ver mundo tan borracho, pasara la vida entre los brutos de los montes; que ésta es compañía menos fiera que la de un racional pretendiente a bestialidades por sus vicios ${ }^{61}$.

En la «Visión y visita décimatercia», y en una descripción más prolija que la anterior, son de nuevo ambos personajes testigos de los desórdenes humanos, esta vez en una cena de porte rabelesiano en la que, más allá del regusto rítmico de la prosa, de los exagerados tintes descriptivos y de la reiterada intención crítica, interesa reparar en los detalles referentes a los usos de la mesa (protocolo, cubertería, menú...):

Acabaron el baile, despidiéronse unos y quedáronse otros; llegó el tiempo de cenar, fueron requeridos los criados. Con esto entraron al punto seis o siete ministros de la gula, auxiliares de la destemplanza, terceros de la ahitera y alcahuetes de la borrachez. Extendieron sobre largas mesas delicadísimos manteles; distribuyeron un haz de servilletas, cuchillos, platos, cucharas y tenedores. Tocóse a degollar la razón, a desgarretar la salud, a desenvolver el recato, a espolear la lujuria y a desarrebujar el secreto. Sentáronse todos; empezaron a venir ensaladas de todas las naciones; engulléronse un huerto con aceite y vinagre; siguióse variedad de carnes; desde aquí comenzó la humareda de los mostos a cegar el juicio y a dejar a tientas el alma. Tan impaciente se miraba la voracidad de todos, que más

61 Diego Torres de Villarroel, Visiones y visitas de Torres con don Francisco de Quevedo por la corte, ed. crítica de Russell P. Sebol, Madrid, Espasa Calpe, 1966, págs. 32-34. 
parecía embestir que comer. Cada dos bocados eran colaterales de media azumbre. Tragáronse a la Extremadura en jamones, a Salamanca en pavos; desparecióse San Martín a sorbos, y se enjugó Lucena a buches. Tan presto quería la gula verter los platos en el vientre, que desechando la diligencia del mascar, nos dieron a entender que se podían sorber los perdigones y beberse las pollas. Corrían desguazados por los gaznates de las hembras los ríos de peralta ${ }^{62}$.

La escena continúa, también como en el pasaje anterior, con la comparación entre el «antes» modélico de la época de Quevedo y el «hoy» salido de madre, donde la hartura de la comida viene doblada por la de los vinos y licores: «Uno canta un responso pasado por rosolí; otro hace relinchar un rabel; finalmente, toda la sala era una zahúrda de mamarrachos, un pastelón de cerdos y un archipiélago de vómitos».

El padre Isla (1703-1782), en su conocida novela Fray Gerundio de Campazas, alias Zotes (1758-1770), nos ofrece algunos datos interesantes. Emplea, por ejemplo, de forma reiterada el término sobremesa (sobre comida le llama en otra ocasión) ${ }^{63}$ para referirse a la conversación que sigue a un almuerzo; además describe minuciosamente dos banquetes —en uno de los cuales relata incluso la distribución jerárquica de los asientos- y detalla unos menús que nos permiten hacernos una idea de lo que debía de ser en aquella época una comida de medio pelo, lejos, por tanto, de los refinamientos palaciegos:

No fue la cena espléndida pero fue honrada y decente: dos ensaladas, una cruda y otra cocida, un par de huevos frescos, pavo asado, liebre guisada, y postres de queso y aceitunas.

Diose principio a la comida según la loable costumbre de Campos en mesas de mayordomía, con un plato de chanfaina. Hubo su cordero asado, sus conejos, su salpicón, su olla de vaca, carnero, cecina, chorizos y jamón, todo ello en abundancia, sirviéndose por postres aceitunas, pimientos y queso de la tierra; suponiéndose que no sólo andaba rodando por las mesas el vino del Páramo, sino que el de la Nava hizo rodar por los suelos al cabo de la comida a más de dos convidados ${ }^{64}$.

A la descripción de los menús de cada uno de esos dos almuerzos, le siguen los versos y sentencias que se cruzan los comensales — paráfrasis cultas de los alimentos que van saliendo a la mesa, en un caso, y pullas que se cruzan entre

62 Ibídem, págs. 95-100.

63 José Francisco Isla, Historia del famoso predicador fray Gerundio de Campazas, alias Zotes, ed. de Enrique Rodríguez Cepeda, Madrid, Cátedra, 1995, págs. 537, 655 y 656.

64 Ibídem, libro III, capítulo IV, pág. 537; y libro IV, capítulo v, pág. 646. 
sí, en el otro- , de modo que se traslada al lector la sensación de que el novelista «mima», por así decir, las referencias al ceremonial de los banquetes. A más abundamiento, en otro pasaje encontramos un prolijo y perogrullesco excurso acerca de la conveniencia de que las cocinas estén cerca del comedor a fin de que los platos no lleguen fríos a la mesa. Y por si lo que dice el sentido común no fuera suficiente, el narrador invoca la autoridad de un imaginario experto en la materia, «monsieur Ferneyer», cuyo testimonio se transcribe en francés (lo obviamos por abreviar la cita) para traducirlo a continuación al castellano:

[...] habiendo para eso la congruencia de estar muy inmediata la cocina [a la mesa], como lo notó sabiamente monsieur Ferneyer, primer cocinero de su alteza real el señor duque de Orleáns, en su docto tratado El cocinero a la moda, capítulo segundo: Del sitio donde se debe colocar la cocina [...]. «Conviene — dice el docto autor- que se fabrique la cocina lo más cerca posible del cuarto donde se come, y es la razón porque así los platos saldrán a la mesa con el temperamento con que deben salir ${ }^{65}$.»

Todo lo anterior está en abierta y flagrante contradicción con el comienzo del capítulo V de la segunda parte, al que pertenece también el pasaje anterior, donde se ningunean sin miramientos las cuestiones tocantes a la comida y al ceremonial de la mesa por considerar que atentan contra el principio de decoro artístico, que exigiría dejar de lado asuntos de baja nota — la comida, entre ellos- en un relato de pretensiones subidas, como supuestamente pretendía ser la novela:

No es nuestro ánimo hacer una pomposa descripción de la gran mesa, ni referir el orden de asientos que guardaron entre sí los convidados, ni mucho menos dar al lector una individual y menuda noticia de los platos que se sirvieron en ella. Sobre que podría parecer a muchos una prolijidad impertinente, no faltarían acaso algunos que la calificasen de impropia o de muy ajena a aquella majestad que debe reinar siempre en esta gravísima historia, en la cual nunca pueden hacerse lugar oportuno noticias que no sean de la mayor importancia; porque si bien no pocos historiadores no han dado en esto ejemplo harto pernicioso, haciéndole en las suyas a cosas asaz extravagantes y ridículas, como el que se paró muy de propósito a tomar la media a las bragas de Calígula ${ }^{66}$.

65 Ibídem, libro IV, capítulo v, pág. 644. En la relación de recetarios franceses de la época no aparece ningún monsieur Ferneyer, si bien el título que aduce Isla evoca a algunos de los realmente publicados: Le Cuisinier moderne, La Cuisinière bourgeoise, La Cuisinière republicaine, Manuel du cuisinier amateur...; vid. Hyman, art. cit., págs. 811-812.

66 IsLa, Historia del famoso predicador, libro IV, capítulo v, pág. 642. 
Pues bien, el capítulo entero que sigue a esta historiada introducción -y de la que sólo copiamos una pequeña parte - está dedicado justamente a lo contrario del propósito inicial, ya que cuenta al pormenor la cena que tuvo lugar en casa de Antón Zotes. Tal contradictorio y repentino cambio de opinión no puede atribuirse ni a olvido ni a incoherencia y entendemos que debe ponerse en relación con la logomaquia general de esta disparatada historia.

El sainetista Ramón de la Cruz (1731-1794) es una fuente importante de datos para nuestro propósito — que en la extensión de un artículo, por supuesto, no podemos agotar-, porque sus personajes se mueven muy a menudo en ambientes de festejos y comidas de ambiente castizo, y, curiosamente, porque con frecuencia emplean la comida como metáfora y como visión del mundo ${ }^{67}$. Pone también en boca de algunos vendedores ambulantes de comida sus respectivos pregones, por ejemplo, en su sainete Las castañeras picadas éste que canta la castañera Pintosilla:

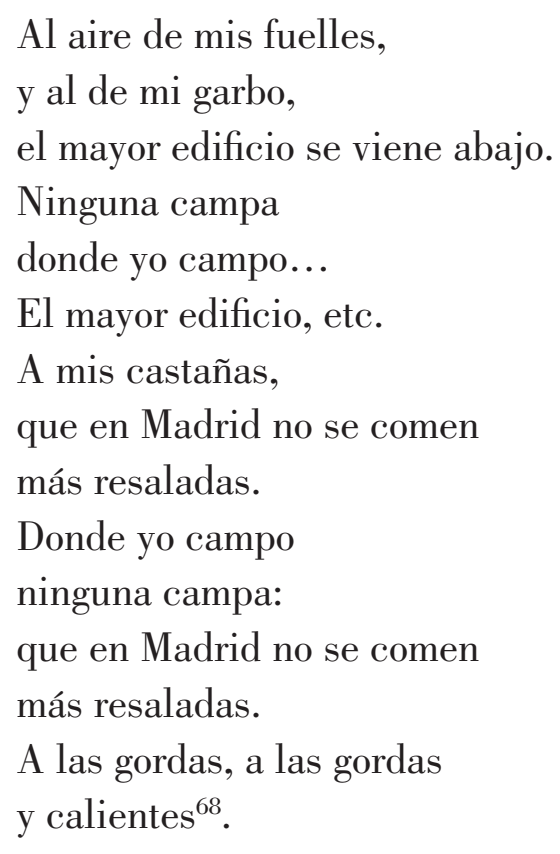

En el sainete titulado precisamente El cocinero (1769), su protagonista, monsieur Andoville, desgranaba unos versos, citados más atrás, que ridiculizan la moda desmedida de seguir en la comida los usos foráneos. En La civilización

67 Un par de ejemplos: en El deseo de seguidillas (1769), un personaje alude de este modo a los tipos disfrazados en danzas populares: «A mí nada / me divierte en no saliendo / el de los botones gordos, / el cagala-olla, el viejo, / y no habiendo tonadillas para rematar el cuento». En Los bandos de Lavapiés se emplea la expresión «pan de perro» (v. 2).

68 Ramón de la Cruz, Sainetes, Madrid, Cátedra, 1990, ed. de Francisco Lafarga, págs. 365-366. 
hace en un tono caricaturesco la descripción de una botillería, un establecimiento de bebidas y refrescos:

$\begin{array}{ll}\text { Abate.- } & \text { ¿Qué buen despacho tuviera } \\ \text { Alcalde.- } & \text { aquí una botillería! } \\ \text { Payo } 2^{\circ} \text {.- } & \text { Alcamos qué cosa es ésa. } \\ & \text { porque estuve en una de ellas. } \\ & \text { Una casa adonde hacen } \\ & \text { unas aguas tan espesas } \\ & \text { que se comen con cuchara; } \\ & \text { a otros les dan a que beban } \\ & \text { garbanzos y pan; y, como } \\ & \text { si estuvieran en Guinea, } \\ & \text { les dicen que es pan de España, } \\ & \text { ioh qué lindas tragaderas! } \\ & \text { Allí van mujeres y hombres } \\ & \text { y dicen que se refrescan; } \\ & \text { y hay unos lances, iqué lances! } \\ & \text { ¡Dios nos libre y nos defienda! } \\ & \text { Beber pan y comer agua } \\ & \text { no puede ser cosa buena } \\ & \text { al estómago }{ }^{69} .\end{array}$

En Los bandos de Lavapiés se pormenoriza lo que podría ser el menú de una comida popular:

\author{
Fue el caso que cierto día \\ vi que entró en casa de Pedro, \\ el tabernero, y con ella \\ Perdulario el zapatero, \\ detrás de ellos entré yo; \\ piden pan, piden sardinas, \\ y para postre pimientos ${ }^{70}$.
} daura, pág. 24 .

${ }^{69}$ La civilización, en Ramón DE LA Cruz, Sainetes, Barcelona, Crítica, 1996, ed. de J. M. Sala Vall-

70 Los bandos de Lavapiés, vv. 157-164. 
El Viaje de España (1772-1794) de Antonio Ponz (1725-1792) comprende dieciocho volúmenes que contienen un vastísimo repertorio de los monumentos de buena parte de España, y naturalmente cae fuera de nuestro tema; sin embargo, encontramos algunos comentarios sobre posadas, fondas y casas de postas que sí nos interesan. La obra, realizada por encargo del conde de Campomanes, presidente del Consejo de Castilla, está escrita en forma epistolar, tal como denotan algunos pasajes. En general, las valoraciones que establece son negativas, señalando que «las posadas nunca serán buenas en España mientras no se aparten varios impedimentos», que enumera a continuación, para concluir que «así huyen los extranjeros de caminar por España, y los naturales dejan de hacerlo por no verse en calamidades ${ }^{71}$ ».

Como si estuviera constatando que la excepción confirma la regla, habla de las excelencias de una fuente que encuentra cerca de Segorbe (Castellón):

El agua de esta fuente es muy saludable, clara y del mejor sabor. No cría ranas, ni mosquitos ni otras sabandijas, ni se corrompe detenida, ni cría ovas. Petrifica raíces ni ramas de arbustos, y aun hierbas secas de las de sus orillas y los canales mismos por donde casa, notándose que donde corre más violenta y golpeada depone más materia pétrea, la cual es porosa y semejante a la piedra pómez. Sin embargo de tal calidad, [que] no adolecen estos moradores del cálculo o mal de orina ${ }^{72}$.

No en todos los casos la visión de los mesones es negativa, como en el de Ranera (Guadalajara), en que el balance es positivo:

Di con el mesón, que no manifestaba más capacidad que la de una angosta entrada, ni más sobre qué recostarse que sus duras piedras. Afligíme al ver el mal rato que me esperaba, y más viniendo fatigado del calor y de tan mal camino; pero, en medio de esto, tuve fortuna de encontrar lo que en la mayor parte de nuestras posadas no se encuentra, que es agrado y buen modo en la mesonera. Con esto ya fue todo mejor de lo que creía; y en cuanto a la comida, asó un gran trozo de carnero (que el de la Alcarria es de lo bueno que hay en España), nos procuró algunos huevos y fruta, y en su angostosísima cocina me acomodé con mi comitiva, satisfaciendo maravillosamente el apetito, a que también contribuyó el exquisito vino de este pueblo. Aún me faltaba otra cosa para que del todo quedase desmentido el mal concepto que formé del alojamiento, y era la cama en que reposar la siesta. Al

71 Antonio Ponz, Viaje de España, Madrid, Aguilar, 1988 [1. a ed., 1947], tomo VIII, págs. 627-628.

72 Ibídem, tomo IV, pág. 736. 
instante que aquella mujer lo entendió, me llevó a un aposentillo con mucho aseo y [más] pobre que el de un capuchino, en donde con mucho aseo me tenía compuesta una camilla; dormí un buen rato hasta que me llamaron ${ }^{73}$.

Muy cercanas al tópico del «menosprecio de corte y alabanza de aldea» e igualmente favorables son las referencias a «cierto lugar de los que hay entre Cuenca y este territorio, el que por cierta razón dejo de nombrar, [donde] fui recibido en casa de una persona de todas circunstancias»:

Los manjares no le puedo decir a usted cuán bien me supieron. Ni perdices más bien guisadas, ni carnero más tierno ni con más sazón asado, estoy por decirle que no se ha comido hasta ahora. Todavía me parece sentir el olor de ciertos torreznos, que fue uno de aquellos platos sin artificio ni transformación alguna, como se practica en las mesas de los poderosos, y, sobre todo, encontrados sin afán, ni con aquellas exquisitas diligencias con que, a fuerza de gastos increíbles, se cubren las mesas de los magnates ${ }^{74}$.

El Viaje fuera de España (1785) recoge las impresiones de su viaje por los Países Bajos, Francia e Inglaterra, y en él aparece una elogiosa descripción de los establecimientos londinenses de venta ambulante de comida, así como de sus tabernas:

Los que venden fruta y otras cosas por las calles, así hombres como mujeres, parece que van cantando, en especial las mujeres, llevando sus géneros con el mayor aseo en unos carritos curiosos, que con facilidad van empujando hacia delante, cubiertas siempre las frutas y lo demás con manteles muy limpios, y ellas se ven igualmente aseadas.

Esta limpieza se observa generalmente en las carnicerías, pescaderías y en casi todos los parajes donde se venden comestibles; pero no falta quien no se la conceda a las manos de los vendedores, tachándolos de tener pesos falsos para hacer y no hacer uso de ellos, según es el comprador. Entre las infinitas hosterías, que aquí llaman tabernas, dio la casualidad de que yo comiese un día en la conocida con el nombre de Taberna de Londres, muy nombrada en las gacetas [...].

No le puedo ponderar a usted la magnificencia y ornato de las salas donde se comió y de otras muchas de la tal taberna, que más parecía un palacio que otra cosa; pero cuando vi que al final de la comida pagó cada uno de los convidantes dos

73 Ibídem, tomo I, págs. 282-283.

74 Ibídem, tomo III, págs. 594-595. 
guineas, esto es, casi doscientos reales, y que los pagadores eran más de cuarenta, ya no extrañé la abundancia de la mesa ni la propiedad de las salas ${ }^{75}$.

José Cadalso (1741-1782), en sus Cartas marruecas (1789), satiriza las costumbres españolas de la época y en concreto el empleo abusivo de galicismos, entre ellos los referidos a la comida (carta XXXV). Ofrece también un cuadro caricaturesco de la vida española, en el cual encontramos varias alusiones a los hábitos de la mesa:

Son muchos millares de hombres los que se levantan muy tarde, toman chocolate muy caliente, agua muy fría, se visten, salen a la plaza, ajustan un par de pollos, oyen misa, vuelven a la plaza, dan cuatro paseos, se informan en qué estado se hallan los chismes y hablillas del lugar, vuelven a casa, comen muy despacio, duermen la siesta, se levantan, dan un paseo al campo, vuelven a casa, se refrescan, van a la tertulia, juegan a la malilla, vuelta a casa, rezan el rosario, cenan y se meten en la cama ${ }^{76}$.

El Diario de Gaspar Melchor de Jovellanos (1744-1811) contiene un registro de temas variados, recogidos a lo largo de sus viajes por España (encuentros con personas, alusiones casi constantes a la climatología, a los cultivos, a los monumentos, las obras públicas, los caminos, detalles sobre las poblaciones y aldeas por las que transita, etcétera), donde todo lo alusivo a su persona termina en alguna breve referencia a la salud, y poco más. En una ocasión confiesa: «Mi comida es moderada y, por lo común, de legumbres, hortalizas y algún pescado». Y en otra leemos: «Domingo, 17 [de noviembre de 1793]. Cena y a la cama. El chocolate me había desvelado e hizo la noche más triste. Me duermo al fin ${ }^{77}{ }$.

En lo tocante a nuestro tema, lo más habitual son brevísimas reseñas de sus comidas, bien en establecimientos públicos, bien en casas particulares. En alguna ocasión menciona también la mala calidad de los hospedajes. Se trata de notas sucintas en las que alguna vez detalla el menú, y, en lo referente a las fondas, viene a confirmar el testimonio de otros autores que dan cuenta de la precariedad de la hostelería española del momento. He aquí algunas de sus anotaciones:

Domingo, 5 [de septiembre de 1790] [Pajares]. Posada del Gallo, mala casa, buena gente; cuarto alto con tres camas, poco aseado ${ }^{78}$.

75 Antonio Ponz, Viaje fuera de España, Madrid, Aguilar, 1988, tomo II, pág. 309.

76 José Cadalso, Cartas marruecas, carta LXXXv.

77 Gaspar Melchor de Jovellanos, Obras completas, ed. de José Miguel Caso, tomo VI, Oviedo, Instituto Feijoo de Estudios del Siglo XVIII-Ayto. de Gijón, 1994, págs. 484-486.

78 Ibídem, pág. 90. 
Lunes, 20 [de septiembre de 1790]. A comer en la Pola [de Siero], posada nueva de Centi: excelente asistencia; abundancia, limpieza y baratura ${ }^{79}$.

Miércoles, 22 [de septiembre de 1790]. Llegamos a comer a Ribadesella. [...] Lugar desproveído; sólo hallamos huevos; ni carne, ni leche, ni pescado, ni confitería, ni aun barbero ${ }^{80}$.

Día 5, martes [de junio de 1792] [Torrebarrio]. Ninguna posada, ni otra comodidad que la taberna. Comimos, sin embargo, bien porque lo traíamos ${ }^{81}$.

Domingo, 22 [de julio de 1792] [Belmonte]. Comimos magníficamente; buena siesta después ${ }^{82}$.

Lunes, 23 [de julio de 1792] [Cornellana]. Hemos comido tan regaladamente como todos los días, y ahora vamos a partir ${ }^{83}$.

[2 de junio de 1793] [Contrueces, día de campo] Comimos muy bien y alegremente; éramos diez y nueve de primera mesa ${ }^{84}$.

Jueves, 14 [de noviembre de 1793] [Campomanes]. Mala posada. [...] Sin resguardo contra el frío, ni limpieza. [En Pajares] vamos a comer, bien y con ganas ${ }^{85}$.

Lunes, 18 [de noviembre de 1793] [Puente los Fierros]. Cruel posada; falta de todo. Envío a Campomanes por vino y truchas. [...] Llega la gente dadas las tres de la tarde, cansada, pero concluida la operación hasta este pueblo. ¡Gracias a Dios que estamos fuera del puerto! Descansaremos y tomaremos la comida y la cena a un mismo tiempo ${ }^{86}$.

Martes, 19 [de noviembre de 1793]. Me adelanto a pie hasta Campomanes. Mejor posada que la de arriba; más limpia, mejor y más aseada ropa; sala más capaz; mayor abrigo. Es en casa de Felipe; sin embargo, no falta que calafatear ${ }^{87}$.

Miércoles, 20 [de noviembre de 1793]. ¡Qué frío hace! Estas malditas posadas todas pecan de desabrigo ${ }^{88}$.

Viernes, 22 [Pola de Lena]. Comimos muy bien y con bastante finura ${ }^{89}$.

Martes, 26. Comida muy regalada: entre otras cosas una trucha de tres libras y media ${ }^{90}$.

\footnotetext{
79 Ibídem, pág. 95.

$80 \quad$ Ibídem, pág. 101.

Ibídem, pág. 319.

Ibídem, pág. 425.

3 Ibídem, pág. 425.

84 Ibídem, pág. 473.

85 Ibídem, pág. 482.

86 Ibídem, pág. 487.

87 Ibídem.

$88 \quad$ Ibídem, pág. 488.

89 Ibídem, pág. 496.

$90 \quad$ Ibídem, pág. 506.
} 
En otras obras de Jovellanos (Informe sobre la Ley Agraria, Discurso a la Sociedad de Amigos del País de Asturias...) se encuentran no pocas disertaciones sobre cultivo de tierras, comercio de productos alimenticios, etcétera. Mencionaremos sólo dos pasajes más de su Diario. En el primero, después de una detallada descripción del cultivo del maíz, se habla de la esfoyaza, tradicional reunión nocturna, mitad laboral, mitad festiva, donde en las noches del otoño asturiano, con ocasión de la cosecha de ese cereal, se reunía la gente de las aldeas para enristrar sus panojas y, de paso, solazarse:

La operación de la esfoyaza [...] se hace por turnos en las casas de los labradores, concurriendo los mozos de la redonda a ellas: las mujeres desenvuelven las hojas, descubriendo el grano de la mazorca, separando las inútiles y dejando tres o cuatro, y los hombres tejen estas hojas unas con otras formando riestras de cuatro a cinco varas de largo, a que llaman pinones cuando son más cortas. Esta operación es de mucha alegría: se canta mucho; se tiran unos a otros las panoyas; se retoza y se merienda tortillas de sardinas, jamón con borona, precisamente caliente, queso y peras o manzanas cocidas con la misma borona. En otras partes se da a cada uno un panecillo como de media libra, y en otras, garulla, esto es, corbates [castañas asadas con la piel] y peres y manzanes crudas. Esta esfoyaza es siempre de noche, y acaban a la una o las dos. Entonces los galanes acompañan a las mozas hasta su casa, que suelen ser distantes, y al amanecer están en el trabajo. Estas riestras se cuelgan en lo interior de las casas, en lo exterior de los hórreos, y aun en los árboles ${ }^{91}$.

En el segundo se habla de una fiesta o juego ritual del que tuvo noticia en Villasecino, pueblo de la montaña de León, que se practicaba con ocasión de las bodas. Hay que tener presente que la comida tiene una dimensión biológica, pero encierra también un importante factor de integración social, con claras connotaciones rituales, como en este caso:

Día 5, martes. [...] Había una boda en el pueblo, y con ese motivo supimos un estilo digno de apuntarse, y llaman correr la guerreifa. Dase este nombre a un pan hecho de harina de trigo, leche y huevos; le hace la madrina, y alguna vez llega a arroba de peso. Este pan se pone en manos del padrino, sentado en campo abierto, y a su lado dos mozos para lo que se dirá. Hecho esto, todos los mozos del pueblo y de la redonda que vienen a la boda se ponen o presentan en fila de frente, asidos de la mano, y a la voz o señal del padrino se arrojan todos a correr, y el primero

${ }^{91}$ Ibídem, págs. 123-124. 
que llega gana el primer bocado de la guerreifa por premio, y el resto se reparte sin distinción entre los concurrentes; esto en medio y a la vista de todo el pueblo. Cuando el matrimonio es de viudos, como el presente, no hay fiesta ${ }^{92}$.

Leandro Fernández de Moratín (1760-1828) ofrece un variado muestrario de referencias gastronómicas después de su viaje por Bélgica, Alemania, Suiza e Italia en su Viaje a Italia, que inició cuando contaba treinta y dos años y apareció en edición póstuma (1867). Sus alusiones al tema ofrecen un abierto contraste entre todo lo bueno que pudo encontrar en Europa y lo ruin de algún establecimiento hotelero en el que recaló. A menudo, junto a la admiración por lo que ve fuera de España, se hace explícita la añoranza de que pudiera encontrar lo mismo en su país. Veamos lo que dice del café que conoció en Bruselas:

Hay dentro de él [parque] un café magnífico que consiste en un gran salón decorado con buena arquitectura, e inmediato a él varios gabinetes mui graciosos, juegos de billar y un pequeño teatro donde representan piezas ligeras de música y declamación. ¡Quándo se verá en Madrid esta reunión de placeres que son tan necesarios para entretener el ocio de una corte! ${ }^{93}$

Y lo mismo de la vida regalada y del ambiente en los lugares de recreo en Venecia, si bien advierte que no todo el mundo puede permitirse los lujos de la minoría ociosa:

En Venecia se levantan tarde, comen tarde, cenan tarde, y se acuestan tarde. Por las mañanas salen en su góndola con basquiña y cendal; las viejas se van a misa y a visitar monjas, y las mozas con sus maridos o sus amantes a dar un paseo por la plaza de San Marcos, y a pasar un par de horas en los casinos en buena compañía y tomar café, siendo de advertir que en Venecia suelen tomar café siete u ocho u [sic] más veces al día, bien que el café es excelente y las tazas pequeñas. Después del teatro, se juntan, o en los casinos o en las casas particulares, y dura la conversación o el grupo toda la noche, sale el sol y se van a la cama, todo esto debe entenderse de la gente culta y de buen tono, por que [sic] la canalla tiene otras horas y otros estilos ${ }^{94}$.

92 Ibídem, pág. 319. Esta costumbre, copiada casi textualmente, aparece en la entrada «Villasecino» del Diccionario geográfico-estadístico de España y Portugal de Sebastián Miñano, Madrid, 1828.

93 Leandro Fernández de Moratín, Viage a Italia, ed. crítica de Belén Tejerina, Madrid, Espasa Calpe, 1988, pág. 113.

94 Ibídem, pág. 405. 
La buena comida que le sirven en Appenheim le lleva a comentar lo distintas que son las cosas en España:

Comí en Happenheim, lugar pequeño situado al pie de unas montañas, delicioso en extremo por su amenidad y frescura, pero en este lugarejo de quatro casas, distante de toda corte opulenta, iqué posada!, iqué sopa con huevo desleído a la alemana!, ¡qué buen caldo de carnero!, quando en las Rozas, en Canillejas o en Alcorcón haya otro tanto, entonces para mí tengo que no se gastará el tiempo en escribir apologías ${ }^{95}$.

Y parecida admiración le suscitan las fondas que conoce en Friburgo:

Hay varias hosterías o fondas cerca de la ciudad, que se abren los domingos para el público, en ellas hay salas de bayle con su pequeña orchestra, juegos de bochas y billar, cerveza, vino, refresco y comidas. Aquí concurren hombres y mugeres de la mediana e ínfima clase, meriendan, beben, juegan, y baylan ${ }^{96}$.

La cena con que se regala camino de Lucerna le lleva de nuevo a manifestar lo diferentes que son las cosas aquí:

Hize noche en medio de estos montes en un lugar infeliz, en cuya posada hallé una buena sopa, una excelente tortilla, pichones, pollos, jamón, un buen guisado de baca, manteca, queso, barquillos y vino tinto y blanco. Apologistas, ¿se halla esto en Villaverde a las onze de la noche?97

Cuando describe la abundancia de alimentos que encuentra en Nápoles, hace una curiosa observación —más sarcástica que ingenua, creemos- en la que afirma que el pueblo, aunque no coma, se conforma porque sabe que tiene qué comer:

Nápoles es acaso la más abundante en comestibles que haya en Europa, ya que se atribuye a la prodigiosa fertilidad de sus contornos, o al constante zelo de sus magistrados en esta parte, lo cierto es que admira la abundancia de mantenimientos que se ve por sus plazas y calles: pan, carnes, embutidos, pescados, legumbres, frutos, verduras, quesos, pastas, dulces, bebida, vino, licores; desde lo más necesario a la conservación de la vida hasta lo más exquisito que han inven-

95 Ibídem, pág. 129.

$96 \quad$ Ibídem, pág. 135.

${ }_{97}$ Ibídem, pág. 142. 
tado las artes para alagar la gula, todo se presenta a la vista pública; y el vulgo está contento quando, aunque no coma, sabe que tiene que [sic] comer $^{98}$.

Después del periplo europeo, de vuelta ya a su país, bien pronto comienza a constatar las diferencias («Ya empiezo a conocer que estoy en España», se lamenta $^{99}$ ), y lo que dice de la fonda donde se aloja en Algeciras viene a coincidir con el testimonio de otros muchos autores, nativos o extranjeros:

Estube alojado en la única posada del pueblo. La patrona era la mujer más desabrida que he visto y aún por eso la llaman Mariquita sin gusto. El cuarto no tenía vidrieras, por cada rendija de las ventanas cabía un brazo; sobre mi cama chorreaban dos o tres goteras. La comida que me daban consistía en un plato de sopas, otro de berzas mal cocidas, sepultado en ellas un pedazo de tozino, y nada de carne porque, según me dijo la señora Mariquita, no había en el lugar ni vaca ni carnero, un pesquezo o un alón de pabo que podía volar según las plumas que tenía y un platillo con dos docenas de pasas y otro con seis o siete aceitunas. Este cuarto, esta comida y una jícara de chocolate purgante que tomaba por desayuno me costaba 25 reales cada día ${ }^{100}$.

No todo son alusiones admirativas, porque, cuando encuentra cosas negativas, las anota igualmente. Así, cuando habla del «pestilente humo de tabaco en los cafés» de Appenheim ${ }^{101}$, de la desagradable compañía de mesa en Rastadt, un «postillón que se limpiaba los mocos con la servilleta ${ }^{102}{ }$, del lamentable vino suizo («El vino de Suiza es un vinillo que, si fuese algo más fuerte, parecería vinagre aguado ${ }^{103}$ ) o la desastrosa cena de Velletri:

¡Oh!, quien pudiera pintar la cara del posadero y las de sus criados. Su tono grosero, áspero y desagradable, y más que todo, la avaricia sórdida que reynaba en aquella gruta de ladrones, donde fue menester ajustar ochavo a ochavo el cuarto, la cama y la cena de aquella noche, diligencia absolutamente necesaria en estos paýses, so pena de que a uno le pidan al salir quanto se les antoje, sin conciencia, y lo que es peor, sin apelación. La cena fue correspondiente a la cara del hostelero ${ }^{104}$.

\footnotetext{
98 Ibídem, pág. 234.

99 Ibídem, pág. 629.

$100 \quad$ Ibídem, pág. 629.

101 Ibídem, pág. 131.

102 Ibídem, pág. 132.

103 Ibídem, pág. 149.

104 Ibídem, pág. 211.
} 
Se habrá podido constatar la frecuencia con que aparecen datos que denotan contrastes: resquicios de ideas de antaño frente a la afirmación de la modernidad, lujos palaciegos frente a la sobriedad conventual, opulencia de la cocina cortesana frente a la precariedad de las ventas y a las sucintas recetas populares, tradiciones que conviven con novedades ultramontanas... A estos contrastes queremos añadir para terminar una curiosidad graciosa, una primorosa nadería. Se trata de la dieta de la cotorra del futuro duque de Parma, hijo de Felipe V: «Frutas, sopa, chocolate 1 libreta; 1/4 de vino, 1/4 de bizcochos, 1/4 de almendras», y la sarta de aleluyas que debía recitarle su cuidador por que no olvidara cuanto sabía parlotear:

Por la mañana empieza a hablar diziendo el Bendito. Después: ¿¿Ay pan y chocolate para la cotorrita que se muere de ambre todita? Prosigue diziendo: ¡Ay, que me dan porque pido! Pan, no lo pida la perra y no le darán. Después: ¿Cotorrita, has almorzado? Muy fino está el chasco y no le han dado. Después: Cotorrita, todos los frayles, todos, todos son mis compadres, y las mongicas del Carmen son mis comadres. Luego prosigue: ¿Cotorrita, quién pasa? El Santísimo Sacramento, que va a su casa. Aparta, aparta, cavallero, que pasa el rey de los Cielos. [...] Sabe los nombres siguientes: Gaspar, Jacobo, Pedro, Juan, Aguador, Agua, de la Peña, Benaca. Dice también: Corridito va el cavallero que se le cayó la capa, y el sombrero. [...] También save decir: ¿Para qué quiere el pastor sombrerito para el sol? Para guardar su ganado no le pique el sol ${ }^{105}$.

105 Cit. por Simón Palmer, La cocina de palacio, págs. 78-79. 